\title{
On the vertical distribution of the chlorophyll $a$ concentration in the Mediterranean Sea: a basin-scale and seasonal approach
}

\author{
H. Lavigne ${ }^{1}$, F. D’Ortenzio ${ }^{2,3}$, M. Ribera D’Alcalà ${ }^{4}$, H. Claustre ${ }^{2,3}$, R. Sauzède ${ }^{2,3}$, and M. Gacic ${ }^{1}$ \\ ${ }^{1}$ Istituto Nazionale di Oceanografia e di Geofisica Sperimentale - OGS, Dip. di Oceanografia, \\ Borgo Grotta Gigante 42/c, 34010 Sgonico (Trieste), Italy \\ ${ }^{2}$ CNRS, UMR 7093, Laboratoire d'Océanographie de Villefranche, 06230 Villefranche-sur-Mer, France \\ ${ }^{3}$ Université Pierre et Marie Curie, Paris 6, UMR7093, Laboratoire d'Océanographie de Villefranche, \\ 06230 Villefranche-sur-Mer, France \\ ${ }^{4}$ Laboratorio di Oceanografia Biologica, Stazione Zoologica “A. Dohrn”, Villa Comunale, Napoli, Italy \\ Correspondence to: H. Lavigne (hlavigne@ogs.trieste.it)
}

Received: 16 January 2015 - Published in Biogeosciences Discuss.: 6 March 2015

Revised: 21 July 2015 - Accepted: 21 July 2015 - Published: 26 August 2015

\begin{abstract}
The distribution of the chlorophyll $a$ concentration ([Chl $a]$ ) in the Mediterranean Sea, mainly obtained from satellite surface observations or from scattered in situ experiments, is updated by analyzing a database of fluorescence profiles converted into [Chl $a]$. The database, which includes 6790 fluorescence profiles from various origins, was processed with a specific quality control procedure. To ensure homogeneity between the different data sources, $65 \%$ of fluorescence profiles have been intercalibrated on the basis of their concomitant satellite [Chl $a$ ] estimation. The climatological pattern of [Chl $a$ ] vertical profiles in four key sites of the Mediterranean Sea has been analyzed. Climatological results confirm previous findings over the range of existing [Chl $a$ ] values and throughout the principal Mediterranean trophic regimes. They also provide new insights into the seasonal variability in the shape of the vertical [Chl $a$ ] profile, inaccessible through remote-sensing observations. An analysis based on the recognition of the general shape of the fluorescence profile was also performed. Although the shape of [Chl $a$ ] vertical distribution characterized by a deep chlorophyll maximum (DCM) is ubiquitous during summer, different forms are observed during winter, thus suggesting that factors affecting the vertical distribution of the biomass are complex and highly variable. The [Chl $a$ ] spatial distribution in the Mediterranean Sea mimics, on smaller scales, what is observed in the global ocean. As already evidenced by analyzing satellite surface observations, midlatitude- and subtropical-like phytoplankton dynamics
\end{abstract}

coexist in the Mediterranean Sea. Moreover, the Mediterranean DCM variability appears to be characterized by patterns already observed on the global scale.

\section{Introduction}

\subsection{Surface chlorophyll distribution}

Chlorophyll $a$ concentration (hereafter [Chl $a$ ]) is the main proxy of phytoplankton biomass (Strickland, 1965; Cullen, 1982), representing a key oceanic biogeochemical variable. However, in the Mediterranean Sea, as in the global ocean, comprehensive knowledge of [Chl $a$ ] spatiotemporal variability has been prevented due to a lack of in situ observations (Conkright et al., 2002; Manca et al., 2004). The understanding of the [Chl $a$ ] distribution is essentially restricted to the surface, as it is based on remote-sensing observations. In the Mediterranean Sea, ocean color sensors, such as CZCS (Coastal Zone Color Scanner; Feldman et al., 1989) or SeaWiFS ( Sea-viewing Wide Field-of-view Sensor; McClain et al., 1998), provide observations with high temporal and spatial resolution over the whole basin (Morel and André, 1991; Antoine et al., 1995; Bosc et al., 2004).

As in situ observations have demonstrated (Dolan et al., 1999, 2002; Ignatiades et al., 2009), satellite data confirm the oligotrophic nature of the basin (Dugdale and Wilkerson, 1988) as well as the east-west gradient in oligotro- 

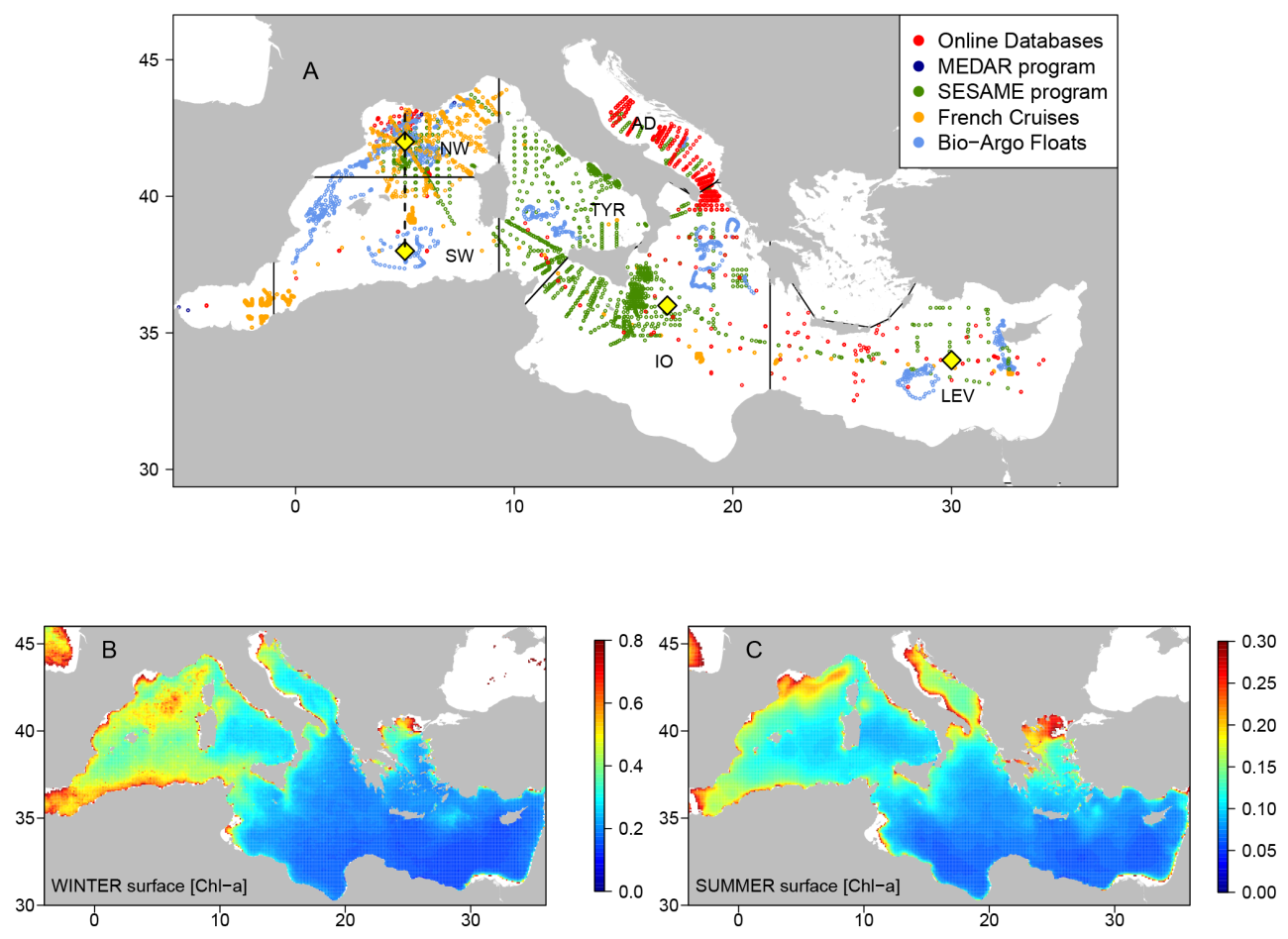

Figure 1. Panel (a): spatial distribution of fluorescence profiles available in the database. Colors indicate the source of data. Black lines delineate large Mediterranean regions: they are referred to as NW for "northwest", SW for "southwest", TYR for "Tyrrhenian", AD for "Adriatic", IO for "Ionian" and LEV for "Levantine". Yellow diamonds refer to the center of region for which a climatology of [Chl $a$ ] vertical profile has been computed (see Fig. 3), and the dashed black line shows the center of the northwest transect (see Fig. 4). Panels (b) and (c): SeaWiFS climatology of surface [Chl $a$ ] for winter (b) and summer (c). Note that color scales are not the same.

phy (see Fig. 1b and c). Excepting the Liguro-Provençal region, where a large spring bloom takes place, and some localized spots, most of the basin exhibits very low values $\left(<0.2 \mathrm{mg} \mathrm{m}^{-2}\right)$ of satellite surface $[\mathrm{Chl} a]$. Surface [Chl $\left.a\right]$ decreases eastward (Bosc et al., 2004; Barale et al., 2008), displaying a sharp gradient between the west and east basins (mean [Chl $a$ ] is about $0.4 \mathrm{mg} \mathrm{m}^{-3}$ in the west basin and $0.05 \mathrm{mg} \mathrm{m}^{-3}$ in the east basin; Bosc et al., 2004; Fig. $1 \mathrm{~b}$ and c). Superimposed on this general pattern, ocean color data also provide insights into the occurrence and the influence of meso- and sub-mesoscale structures on [Chl $a$ ] (TaupierLetage et al., 2003; Navarro et al., 2011, D'Ortenzio et al., 2014).

Satellite observations have also been the primary source of information for the characterization of the $[\mathrm{Chl} a]$ seasonal and interannual variability (D'Ortenzio and Ribera d'Alcalà, 2009; Volpe et al., 2012; Lavigne et al., 2013). On a global scale, ocean color satellite observations indicate that surface $[\mathrm{Chl} a]$ annual cycles display different patterns moving from a tropical to a temperate or a polar environment (Yoder et al., 1993), generally following latitudinal gradients. Boundaries between large ecological regions have been determined from satellite observations, in the global ocean (Longhurst, 2006) but also on regional scales (Devred et al., 2007; D'Ortenzio and Ribera d'Alcalà, 2009; Platt et al., 2010). Indeed, fo- cusing on ocean color observations, D'Ortenzio and Ribera d'Alcalà (2009) confirmed the presence, in the Mediterranean Sea, of surface [Chl $a$ ] annual cycles, displaying similarities with subtropical or with temperate regions. The authors demonstrated that a subtropical-like [Chl $a$ ] seasonality (highest $[\mathrm{Chl} a]$ during winter and lowest during summer) encompasses most of the basin, whereas a temperatelike seasonality, marked by a high peak of surface $[\mathrm{Chl} a]$ in spring (in March and/or April), is recurrently observed in the northwestern basin and occasionally in other Mediterranean regions. Further analysis (Lavigne et al., 2013) showed that the coexistence of different regimes in the Mediterranean Sea is mainly due to the high variability in the interplay between physical forcing, which affects the mixed layer depth (hereafter MLD), and chemical forcing (i.e., nutrient availability).

\subsection{The vertical [Chl $a]$ distribution}

Contrary to the horizontal distribution of [Chl $a$ ], which, despite the uncertainties due to the impact of bio-optical processes (see below), is regularly assessed within the basin as low cloud coverage allows high-frequency measurements, vertical distributions of $[\mathrm{Chl} a]$ are much less documented due to in situ undersampling and to the intrinsic limits of 
color remote sensing in the retrieval of information from subsurface layers.

So far, the largest part of the information derives from studies conducted at specific sites (e.g., Dolan et al., 2002; Christaki et al., 2001; Estrada et al., 1993; Casotti et al., 2003; Marty et al., 2002; Psarra et al., 2000; Krom et al., 1992), generalizations based on large-scale cruises (Moutin and Raimbault, 2002; Crombet et al., 2011), and synthetic analyses (e.g., Siokou-Frangou et al., 2012) or reconstructions derived from modeling studies (e.g., Macias et al., 2014; Crise et al., 1999). These studies showed that deep chlorophyll maxima (hereafter DCMs) are ubiquitous over the Mediterranean from spring to autumn (Crise et al., 1999; Moutin and Raimbault 2002; Siokou-Frangou et al., 2010). They display a longitudinal deepening from west to east (see Crise et al., 1999 for a review), with their depth ranging from $30 \mathrm{~m}$ in the westernmost area (Dolan et al., 2002) to $70 \mathrm{~m}$ in the south Adriatic and more than $100 \mathrm{~m}$ in the Levantine Sea (Christaki et al., 2001). During winter, DCM generally disappear in the whole basin and the so-called "mixed" shape (Morel and Berthon, 1989; Uitz et al., 2006), characterized by a constant $[\mathrm{Chl} a$ ] from the surface to the bottom of the MLD, is often observed (Krom et al., 1992; Marty et al., 2002; Mignot et al., 2014). Alternatively, a [Chl $a$ ] vertical shape marked by a high subsurface maximum close to the surface (less than $10 \mathrm{~m}$ ) has also been documented for the northwestern basin, during the spring bloom period (Marty et al., 2002; Manca et al., 2004). In spite of these focused studies and the compilation of Chl $a$ climatology provided by the MEDAR (Mediterranean Data Archaeology and Rescue)/MEDATLAS project (Maillard et al., 2005), the spatial distribution of [Chl $a$ ] vertical profiles and their yearly patterns are still poorly documented in the basin. Satellite [Chl $a$ ] values may provide additional information using the approach introduced for global assessments of depthintegrated Chl $a$ values (e.g., Morel and Berthon, 1989). In many instances, (e.g., Bosc et al., 2004) their use was implicit and no specific analysis on the vertical distribution per se was carried out.

As discussed in a recent review by Cullen (2015), there is no unique DCM and its dynamics result from the interactions between external forcing, e.g., the penetration of light into water, the intensity of vertical mixing, and subsurface nutrient distribution and biotic processes, e.g., photoacclimation, grazing and phytoplankton composition. To assess which and how many DCMs exist in the Mediterranean Sea because of its known geographical and dynamical gradients, a starting point is to produce a quantitative characterization of the shapes of these DCMs and of their seasonal evolution, which is one of the main aims of this contribution. In addition, a good appreciation of seasonal changes in vertical [Chl $a$ ] distribution, the other objective of this study, is a first step towards a better understanding of mechanisms controlling seasonal phytoplankton development. It is also essential to better interpret changes in surface $[\mathrm{Chl} a]$ as detected by satellite sensors. This study will help with the biogeographical interpretation of surface $[\mathrm{Chl} a]$ patterns, paving the way for focused area studies based on in situ sampling or autonomous vehicles.

\subsection{Fluorescence}

In situ [Chl $a]$ is obtained from filtered water samples, from which the pigment content was extracted and analyzed. The most accurate results are today obtained by highperformance liquid chromatography (HPLC, Gieskes and Kraay, 1983). Its associated protocols are most often expensive, time-consuming and depend on direct sampling with bottles. It hence provides discrete values on a vertical scale with a limited horizontal and temporal resolution. To overcome the above limitations, fluorescence observations can be used. The estimation of [Chl $a$ ] from the fluorescence technique (Lorenzen, 1966) is based on the chlorophyll $a$ property of absorbing blue light and reemitting it, as fluorescence, in the red part of the spectrum. The quantity of fluorescence emitted by a water sample is proportional to [Chl $a$ ], which can then be easily derived by measuring emitted radiation at red wavelengths. The fluorescence technique therefore represents a noninvasive method to observe continuous vertical profiles of [Chl $a$ ]. Today, fluorimeters commonly equip CTD (conductivity-temperature-depth) sondes and can even be built into autonomous profilers. Indeed, an increasing number of profiling floats and gliders are equipped with a fluorimeter (Johnson et al., 2009), while fluorescence is becoming the main source of data for [Chl $a$ ] vertical profiles. To date, more than 67900 fluorescence profiles are available in the World Ocean Database 2013 (Boyer et al., 2013).

However, fluorescence is only a proxy for [Chl $a$ ], meaning that the fluorescence signal needs to be calibrated for a $[$ Chl $a$ ] estimation. Calibration coefficients ( $\alpha$ and $\beta$, see Eq. 1) provided by manufacturers are only indicative of the response of the sensor to a given Chl $a$ concentration in an extract or in an algal suspension and cannot be applied to all in situ conditions. The fluorescence-to- $[\mathrm{Chl} a]$ ratio is highly variable, since it changes with the taxonomic assemblage or environmental conditions (Kiefer, 1973), or it may be affected by dissolved materials (Rottgers and Koch, 2012). For instance, under low-light conditions, the chlorophyll content per cell can increase while the fluorescence-to[Chl $a$ ] ratio decreases due to the packaging effect (Sosik et al., 1989). In response to supraoptimal light irradiation, phytoplankton triggers photo-protection mechanisms, inducing a drastic decrease in the fluorescence-to-[Chl $a]$ ratio (Kolber and Falkowski, 1993; Müller et al., 2001); this mechanism is called non-photochemical quenching (NPQ). The main result of the NPQ effect is a decrease in fluorescence at the surface, even for constant [Chl $a$ ] (Cullen and Lewis, 1995; Xing et al., 2012).

$[\mathrm{Chl} a]=\alpha \times(\mathrm{FLUO}-\beta)$ 
Better estimates are obtained by determining the empirical coefficients (i.e., $\alpha$ and $\beta$ ) that fit fluorescence with in situ data for each profile (Morel and Maritorena, 2001) or for each cruise (Sharples et al., 2001; Strass, 1990; Cetinic et al., 2009). However, this calibration method based on the existence of simultaneous in situ samples is not always applicable. Alternative calibration methods, independent of concomitant HPLC observations, have therefore recently been developed (Boss et al., 2008; Xing et al., 2011; Mignot et al., 2011; Lavigne et al., 2012). They are based on additional information such as irradiance profiles (Xing et al., 2011), ocean color observations (Boss et al., 2008; Lavigne et al., 2012) or the shape of the fluorescence profile (Mignot et al., 2011). Although these new calibration methods do not reach the accuracy of HPLC-based calibration, they offer an acceptable alternative to extract reliable estimates of [Chl $a$ ] vertical profiles from a large quantity of fluorescence profiles.

\subsection{Outlines}

This study aims at improving knowledge on the spatiotemporal variability in the vertical distribution of the $[\mathrm{Chl} a]$ in the Mediterranean Sea, focusing particularly on $[\mathrm{Chl} a]$ seasonality. For this, all the available proxies of $[\mathrm{Chl} a]$ are merged to build a new database. Special attention is paid to the shape of the [Chl $a$ ] profiles: different patterns can point to different processes controlling the phytoplankton distribution. The spatial and seasonal variability in the DCM, which is one of the most common features in Mediterranean [Chl $a$ ] vertical profiles, is also specifically investigated. The objective of this paper is the description of the variability of [Chl $a$ ] vertical profiles, as they result from the interactions between many factors that can be complex as well as poorly documented. This variability is only discussed with regard to Mediterranean hydrology and light fields.

In the following section, the fluorescence database is presented, including the quality control and calibration procedures that were applied. In the results section, the seasonal and spatial variability in climatological $[\mathrm{Chl} a]$ vertical profiles, derived from fluorescence-based reconstructed [Chl $a$ ] profiles, is presented. Climatological results are completed by the analysis of the shape of the $[\mathrm{Chl} a]$ profiles. Contrary to the climatology of [Chl $a$ ] vertical profiles, the shape analysis is based on normalized [Chl $a$ ] profiles and does not account for the $[\mathrm{Chl} a]$ values. The seasonal variability in occurrences in principal $[\mathrm{Chl} a]$ vertical shapes is also investigated here. In the fourth section, certain methodological points related to the production of climatological patterns are addressed. Results are also compared with previous remotesensing-based observations. Finally, the diversity in Mediterranean $[\mathrm{Chl} a]$ patterns is highlighted in a comparison with the global ocean.

\section{Data and methods}

\subsection{Data set of fluorescence chlorophyll profiles}

More than 6000 chlorophyll fluorescence profiles and their corresponding temperature and salinity profiles from the Mediterranean Sea in areas where bathymetry exceeds $100 \mathrm{~m}$ depth were collected from various data sources (Table 1). These comprise online databases (986 profiles), French cruises (2670 profiles), the MEDAR (228 profiles), the SESAME (Southern European Seas: Assessing and Modelling Ecosystem changes) programs database (1815 profiles) and, finally, fluorescence profiles derived from BioArgo floats (1091 profiles). The profiles cover the whole Mediterranean Basin, although some areas are better represented than others (Fig. 1). Many profiles are available in the northwestern Mediterranean Sea, whereas the southwestern Mediterranean Sea and the Levantine Sea are poorly represented. Available profiles range between 1994 and 2014, all seasons being equally represented (winter $30 \%$ of data, spring $21 \%$, summer $25 \%$ and autumn $24 \%$ ). Although only $16 \%$ of the database are Bio-Argo profiles, they represent half of the available profiles for the 2008-2014 period.

\subsection{Data processing and calibration}

Prior to calibration, a quality control procedure was applied to fluorescence profiles. This comprises a test of uniqueness (to eliminate repetitions of the same profile), the identification of spikes (see D'Ortenzio et al., 2010) and the identification of the signs of fluorometer failure (a portion of profile with exactly the same value or jumps in the fluorescence profile). After this quality control step, 593 profiles were removed from the database. Then, incomplete profiles (i.e., profiles for which the acquisition was not deep enough to display the whole fluorescence shape) were also removed. Profiles with a surface fluorescence value lower than the bottom value were removed from the database (202 profiles removed). In addition, the profiles obtained during the three "long-duration" stations of the BOUM (Biogeochemistry from the Oligotrophic to the Ultra-oligotrophic Mediterranean) cruise (Moutin et al., 2012) were removed from the data set because they had been sampled at a very high temporal frequency within an anticyclonic eddy (Moutin and Prieur, 2012). These 404 profiles, which are therefore not independent, would have overrepresented specific environments in the data set.

The remaining fluorescence profiles (5571 profiles) were calibrated using satellite ocean color matchups as surface references (Lavigne et al., 2012). This method has been validated in the Mediterranean Sea by comparing satellite calibrated profiles and in situ HPLC [Chl $a$ ] data. In the Mediterranean Sea, the calibrated profiles are unbiased and present a median error of $41 \%$, which is reduced to $34 \%$ when compared to climatological averages. In summary (see Lavigne 
Table 1. Description of sources for fluorescence profiles. In this table, only fluorescence profiles obtained in Mediterranean regions where bathymetry is greater than $100 \mathrm{~m}$ are counted. Coastal regions have been neglected.

\begin{tabular}{llr}
\hline & Data source & Number of profiles \\
\hline Online & PANGAEA (http://www.pangaea.de/) & 93 \\
databases & SISMER (http://www.ifremer.fr/sismer/index_FR.htm) & 110 \\
& WOD09 (http://www.nodc.noaa.gov/) & 94 \\
& OGS database (http://nodc.ogs.trieste.it/cocoon/data/dataset) & 689 \\
& SUB-TOTAL & 986 \\
\hline French & PROSOPE (Claustre et al., 2004) & 96 \\
cruises & DYNAPROC (Andersen and Prieur, 2000) & 251 \\
& BOUM (Moutin et al., 2012) & 573 \\
& ALMOFRONT (Claustre at al., 2000) & 1046 \\
& DYFAMED (Marty et al., 2002) & 191 \\
& MOOSE-GE (http://hermes.dt.insu.cnrs.fr/moose) & 285 \\
& DEWEX (Durrieu de Madron et al., 2011) & 228 \\
& SUB-TOTAL & 2670 \\
\hline SESAME Program (http://www.sesame-ip.eu/) & 1815 \\
\hline MEDAR Program (MEDAR Group., 2002) & 228 \\
\hline Bio-Argo (Xing et al.. 2011; http://www.oao.obs-vlfr.fr/web/index.php) & 1091 \\
\hline TOTAL & & 6790 \\
\hline
\end{tabular}

et al., 2012, for a comprehensive description and validation of the procedure), the method consists of (step 1) a correction for the NPQ effect, (step 2) the adjustment to a zero value of the fluorescence profile at depth and (step 3) the application of a calibration coefficient obtained from ocean color satellite matchups. The last step has only been applied to the fluorescence profiles available for the 1998-2014 period (i.e., the time during which SeaWiFS or MODIS (Moderate Resolution Imaging Spectroradiometer) Aqua data were available and could be used to calculate the matchups).

Step 1 provides a systematic correction of the NPQ effect by extrapolating the maximum fluorescence value observed in the mixed layer up to the surface (Xing et al., 2012). Although Biermann et al. (2014) proposed an improvement of the method for profiles with a euphotic depth above the MLD, we preferred to use a unique data processing procedure to avoid the introduction of an artificial bias due to a heterogenic data treatment. The MLD was evaluated from potential density profiles using a density criterion of $0.03 \mathrm{~kg} \mathrm{~m}^{-3}$ (de Boyer Montegut et al., 2004; D’Ortenzio et al., 2005). This method proved to be an efficient NPQ correction in most conditions (Xing et al., 2012; Lavigne et al., 2012), although it presented limitations for shallow MLDs and stratified water columns. By applying the equation proposed by Sackmann et al. (2008) on monthly averaged light fields, the impact of NPQ was observed to be significant only above $60 \mathrm{~m}$, thus leading to a 2-fold underestimation of surface [Chl $a$ ]. Considering this result, the weak efficiency of the NPQ correction method in stratified conditions should not have major consequences for the present study. Only the analysis of the surface-to-integrated-content chlorophyll ratio (see Table 3) should be considered with caution.

Step 2 corrects the systematic instrumental offset, which impacts the whole profile, although it can only be detected at depth. Except for very specific cases, $[\mathrm{Chl} a]$ is considered to reach a zero value at depths where there is no more light availability. If this is not the case, a correction factor (i.e., $\beta$ in Eq. 1) is subtracted from the whole fluorescence profile, considering that the median of the 10 deepest observations is equal to 0 . Profiles in which the MLD was deeper than the deepest fluorescence observation were not processed but were not removed from the database either $(1.1 \%$ of data set). After step 1 and step 2, 5571 profiles were successfully corrected and stored in the so-called "1994-2014 database". These fluorescence profiles were used later for the shape analysis (see Sect. 2.3 and Sect. 3.2).

In step 3, fluorescence profiles collected after 1998 were converted into [Chl $a$ ] units using a transformation based on ocean color satellite observations (Lavigne et al., 2012). Eight-day Level 3 standard mapped images of SeaWiFS and MODIS Aqua surface chlorophyll at a $9 \mathrm{~km}$ resolution were obtained from the NASA web site (http://oceancolor.gsfc. nasa.gov/) for the 1998-2014 period (1998-2007 for SeaWiFS and 2008-2014 for MODIS Aqua). The use of NASA [Chl $a$ ] standard products allows for a good consistency between SeaWiFS and MODIS data sets, thus avoiding the introduction of any bias between the two time series (Franz et al., 2005). For each fluorescence profile, the satellite image matching the profile date was selected. The corresponding surface $[\mathrm{Chl} a]$ values over a $0.1^{\circ} \times 0.1^{\circ}$ box centered on the 


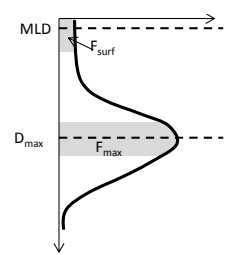

A. DCM
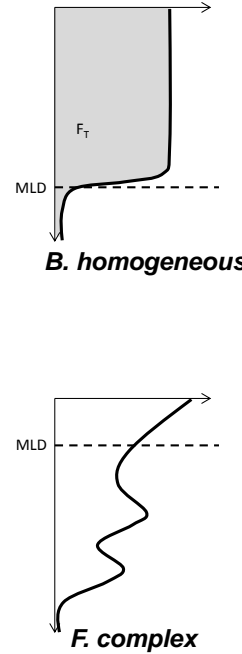

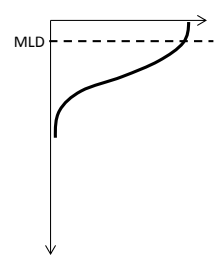

C. HSC

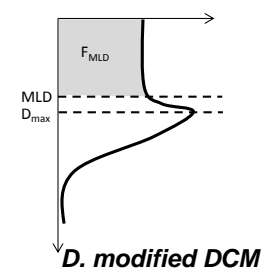

Figure 2. The five standard shapes for [Chl $a$ ] vertical profiles identified in our data set. See Sect. 2.3 of the text for more details about these shapes and for a description of the algorithm used to identify them. Black solid lines represent the normalized [Chl $a$ ] vertical profile. Metrics used for the determination of the profile standard shape (i.e., MLD, $D_{\max }, F_{\text {surf }}, F_{\max }, F_{T}$; see Sect. 2.3 for definitions) are represented on standard profiles. Although all of these metrics have been computed on each fluorescence profile, they could not be represented on the same profile for practical reasons.

geographical position of the profile were extracted and averaged. The integrated chlorophyll content over $1.5 Z_{\mathrm{e}}$ (where $Z_{\mathrm{e}}$ is the euphotic depth) is then estimated from satellite [Chl $a$ ] using empirical relationships (Uitz et al., 2006) and $Z_{\mathrm{e}}$ is calculated from the chlorophyll-integrated content using the equations of Morel and Berthon (1989). A multiplicative coefficient ( $\alpha$ coefficient in Eq. 1) is applied to the fluorescence profile, imposing the condition that the integrated fluorescence content matches the integrated chlorophyll content derived from satellite. In the end, 3867 fluorescence profiles were successfully transformed into [Chl $a]$. These [Chl $a$ ] profiles formed the "1998-2014 database" and, like the fluorescence profiles of the "1994-2014 database", they are available upon request from the first author.

\subsection{Determination of the shape of fluorescence profiles}

On the basis of a visual analysis of the whole database, five general types of fluorescence vertical shapes were identified. These five categories, which represent the most frequent shapes of vertical distribution observed in the Mediterranean, also reflect their conditioning by physical-biological processes. These categories are referred to as DCM, homogeneous, HSC (for high surface chlorophyll), complex and modified DCM on the basis of their general characteristics (Fig. 2). The DCM and homogeneous shapes have been commonly used to describe [Chl $a$ ] vertical profiles (Morel and Berthon, 1989; Uitz et al., 2006; Mignot et al., 2011). They are referred to as "stratified" and "mixed", respectively, and are distinguished according to the relative position of $\mathrm{Ze}$ and the MLD. The $D C M$ shape is characterized by a subsurface DCM, and the homogeneous shape by a positive homogeneous [Chl $a$ ] in the mixed layer. After an examination of the database, three other standard shapes have been introduced (i.e., HSC, modified DCM and complex shapes) to better describe the observed variability. The HSC standard shape was defined for profiles displaying a steady decrease in [Chl $a$ ] from surface to depth $(\sim 100 \mathrm{~m})$, as generally observed during phytoplankton blooms (Chiswell, 2011). The modified $D C M$ shape describes profiles with relatively high values in the mixed layer and with a peak of [Chl $a$ ] just below the MLD. It represents an intermediate condition between the $D C M$ and homogeneous situations. Finally, profiles with a complex shape, often displaying several peaks and a relatively high surface $[\mathrm{Chl} a]$, were classed as standard complex shapes.

To automatically categorize each profile of the 1994-2014 database into one of the five shape classes, a simple algorithm has been used, computing the following metrics for each profile: the depth of fluorescence maxima $\left(D_{\max }\right.$, see Fig. 2a and d), the MLD, the fluorescence-integrated content in a $20 \mathrm{~m}$ layer centered on $D_{\max }\left(F_{\max }\right.$, see Fig. 2a), the fluorescence-integrated content in the $0-20 \mathrm{~m}$ surface layer ( $F_{\text {surf }}$, see Fig. 2a), the fluorescence-integrated content in the mixed layer ( $F_{\mathrm{MLD}}$, see Fig. $2 \mathrm{~d}$ ) and the total fluorescence content $\left(F_{\mathrm{T}}\right.$, see Fig. $\left.2 \mathrm{~b}\right)$.

The algorithm was applied to each profile. It first tests the $H S C$ shape. The HSC shape is assigned to a profile if its fluorescence averaged over layers of a width of $10 \mathrm{~m}$ decreases from surface to $100 \mathrm{~m}$. Secondly, the $D C M$ shape is tested. If the MLD is above $D_{\max }$ and if $F_{\max }$ is twice as large as $F_{\text {surf }}$, the profile is classed in the $D C M$ category. If not, the homogeneous shape is tested. The profile is classed in the homogeneous category if $F_{\mathrm{MLD}} / F_{\mathrm{T}}$ is superior to 0.85 (more than $85 \%$ of biomass contained in the mixed layer). Finally, if the fluorescence profile does not meet any of the previous criteria, it is either classed in the modified DCM category, if the corresponding MLD is above $D_{\max }$, or in the complex category.

Overall, 2780 profiles were classed in the $D C M$ category, 751 in the homogeneous category, 413 in the HSC category, 637 in the modified DCM category and 990 in the complex category.

\section{Results}

\subsection{Some climatological behaviors}

Although the availability of the calibrated profiles (19982014 database) should allow us to generate interpolated products on a regular mesh grid (as, for example, the World Ocean Atlas; Conkright et al., 2002), we preferred to avoid any large 
A. Point: $42^{\circ} \mathrm{N}, 5^{\circ} \mathrm{E} /$ North-West

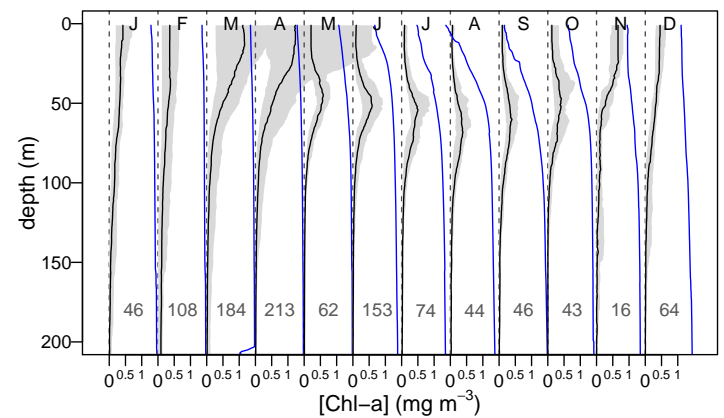

C. Point: $36^{\circ} \mathrm{N}, 17^{\circ} \mathrm{E} /$ lonian

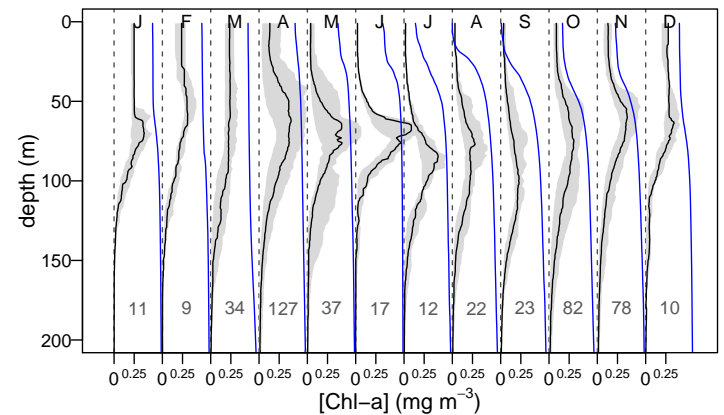

B. Point: $38^{\circ} \mathrm{N}, 5^{\circ} \mathrm{E} /$ South-West

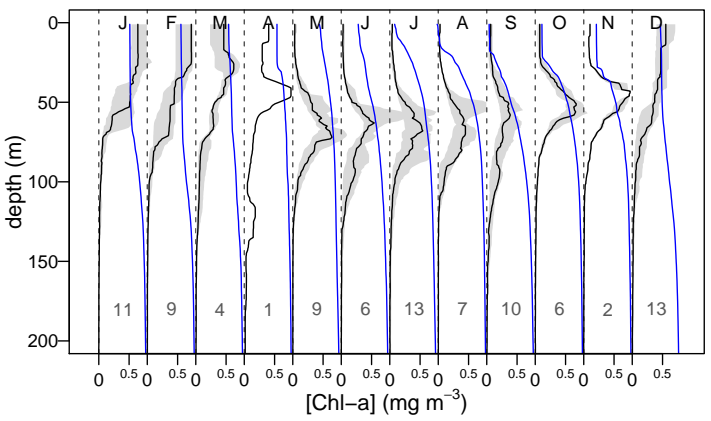

D. Point: $34^{\circ} \mathrm{N}, 30^{\circ} \mathrm{E} /$ Levantine

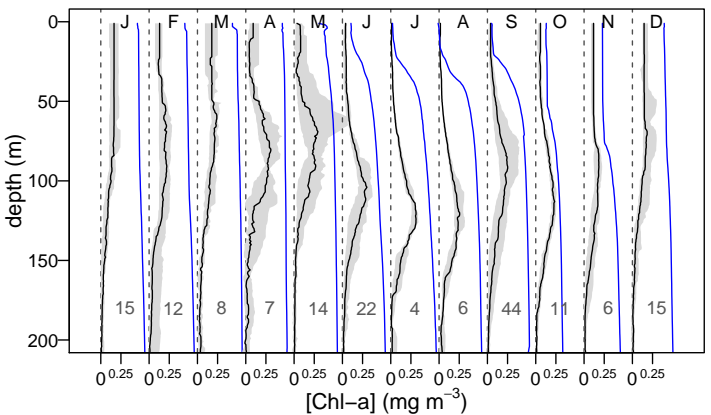

Figure 3. Climatology of [Chl $a$ ] vertical profiles (black lines) for four points of the Mediterranean Sea (see yellow diamonds in Fig. 1). All profiles located within a $4^{\circ} \times 4^{\circ}$ box centered on indicated positions were retained. The median value for each month is the black line. The grey zone indicates the 0.1 -quantile-0.9-quantile range. Numbers below climatological profiles indicate the number of available data profiles used to compute them. Normalized average water density profiles are superimposed (blue lines).

interpolation and only present Mediterranean patterns for locations well represented in our database. Hence, monthly climatologies of [Chl $a$ ] vertical profiles were computed for four geographical areas (i.e., $4^{\circ} \times 4^{\circ}$ boxes) where the data density was high. These locations were also placed in four main Mediterranean subbasins (i.e., centered on $42^{\circ} \mathrm{N}, 5^{\circ} \mathrm{E}$ in the northwestern basin, $38^{\circ} \mathrm{N}, 5^{\circ} \mathrm{E}$ in the southwestern basin, $36^{\circ} \mathrm{N}, 17^{\circ} \mathrm{E}$ in the Ionian Sea and $34^{\circ} \mathrm{N}, 30^{\circ} \mathrm{E}$ in the Levantine Sea; see yellow diamonds in Fig. 1). The monthly time series are presented in the next section (Sect. 3.1.1). Although, in the following, we refer to these time series as "climatological", certain average profiles result from a low number of fluorescence profiles (sometimes less than 10; see numbers in Fig. 3) and therefore do not strictly represent a climatological pattern. To better identify spatial changes in [Chl $a$ ] fields, we also present climatological transects (Sect. 3.1.2). Due to the weak density of data in the eastern basin, the [Chl $a$ ] distribution could only be analyzed along a $5^{\circ}$ E north-south transect in the western basin (see dotted line in Fig. 1). Nevertheless, this transect encompasses regions with different biological dynamics (D'Ortenzio and Ribera d'Alcalà, 2009), and it is representative of the main patterns of the western Mediterranean.

\subsubsection{Seasonality in four geographic locations}

For each of the four selected geographic locations (see above), all available profiles in a $4^{\circ} \times 4^{\circ}$ side box centered on the chosen geographical position were averaged on a $1 \mathrm{~m}$ vertical scale and on a monthly basis to produce climatological profiles. The resulting monthly climatologies are displayed in Fig. 3.

Overall, the climatological time series representing the southwestern basin, the Ionian Sea and the Levantine Sea (Fig. 3b, c and d) display a similar evolution of the vertical $[$ Chl $a$ ] distribution. From December to March, [Chl $a$ ] is greater in the surface layer, i.e., from the surface to the base of pycnocline (Fig. 2b), while the April to November period is characterized by the occurrence of a DCM, concurrent with the development of the seasonal pycnocline close to surface. In the southwestern region, winter profiles present relatively high $[\mathrm{Chl} a]$ in the upper meters ([Chl $a]$ $>0.5 \mathrm{mg} \mathrm{m}^{-3}$ ), whereas in the Ionian, and even more in the Levantine, upper layer [Chl $a$ ] is lower and the base of the pycnocline is deeper (about $150 \mathrm{~m}$ in the Ionian Sea and more than $200 \mathrm{~m}$ in the Levantine Sea). DCM, when occurring, is deeper in the Levantine and Ionian seas than in the southwestern region. The climatological time series in the north- 
western basin (Fig. 3a) displays a different succession. DCM occurs from May to October, when surface stratification of the water column can be observed. In November and December, [Chl $a$ ] vertical profiles display homogeneous concentrations from the surface to the upper limit of the pycnocline, which deepens through mixing processes. In January and February, the water density profiles are nearly constant and $[\mathrm{Chl} a]$ profiles display low and homogeneous concentrations up to $100 \mathrm{~m}$. In March and April, although surface water density slightly decreases, pointing to water column stabilization and/or stratification, surface [Chl $a]$ considerably increases. Finally, all time series are characterized by a deepening of the DCM from May to July and a shallowing from August to September. It appears that in the northwest region, the deepening of the DCM coincides with the deepening of the pycnocline. In the other areas, the pycnocline is much shallower than the DCM and their dynamics seem to be uncoupled until September. In October and November, the base of the surface mixed layer seems to be correlated with DCM.

Regarding [Chl $a$ ] values, regional differences are visible, confirming previous observations on the eastward increase in oligotrophic conditions. The highest [Chl $a]$ value is observed in April, in the northwestern climatology (Fig. 3a), reaching $1.2 \mathrm{mg} \mathrm{m}^{-3}$. However, this mean value is derived from extremely variable observations ranging between 0.3 and $4.2 \mathrm{mg} \mathrm{m}^{-3}$. The southwestern time series shows [Chl $a$ ] values up to $0.5 \mathrm{mg} \mathrm{m}^{-3}$, observed at the surface during winter and at the DCM during summer. In the Ionian climatology, the highest [Chl $a$ ] values can be observed at the DCM, reaching $0.3 \mathrm{mg} \mathrm{m}^{-3}$. Finally, the Levantine climatology displays the lowest [Chl $a$ ], with values rarely exceeding $0.25 \mathrm{mg} \mathrm{m}^{-3}$.

Table 2 presents median [Chl $a$ ] values at the DCM depth, for the four geographic locations analyzed here. Contrary to the DCM [Chl $a$ ] values seen in Fig. 3, the values reported in Table 2 are derived from the median DCM [Chl $a$ ] values extracted individually from each fluorescence profile presenting a DCM. In the northwestern region, [Chl $a$ ] at DCM is often around $1 \mathrm{mg} \mathrm{m}^{-3}$, though it ranges between 0.63 in September and $1.07 \mathrm{mg} \mathrm{m}^{-3}$ in April. At the southwestern point, the averaged [Chl $a$ ] at DCM is $0.88 \mathrm{mg} \mathrm{m}^{-3}$. In the eastern basin, values are twice lower (about $0.55 \mathrm{mg} \mathrm{m}^{-3}$ at the Ionian point and $0.40 \mathrm{mg} \mathrm{m}^{-3}$ at the Levantine point). A seasonal pattern does not clearly emerge from the analysis of the DCM statistics, except that [Chl $a]$ at DCM is generally higher during spring and summer and lower during autumn. Note that median DCM depth [Chl $a$ ] values (Table 2) are higher than the DCM depth [Chl $a$ ] values observed on climatological profiles (Fig. 3) because the averaging process on the latter tends to flatten DCMs (see discussion on Sect. 4.1.2, Lavigne et al., 2012).
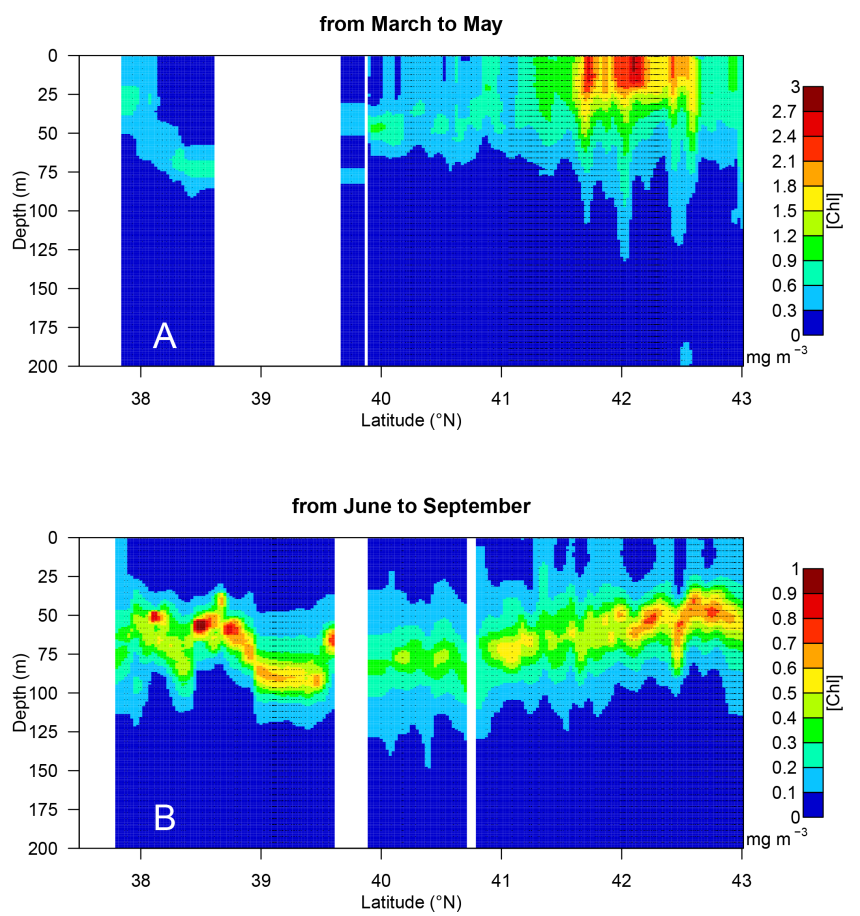

Figure 4. North-south climatological transect of [Chl $a$ ] along the $5^{\circ} \mathrm{W}$ meridian (see the black dotted line in Fig. 1). Panel (a) represents the averaged situation for the March to May period, and (b) does so for the June to September period. Note that color scales are different in (a) and (b). For each available data profile, a vertical dotted line was superimposed on the graph.

\subsubsection{North-south transect}

All the data located within $\pm 2^{\circ}$ from the $5^{\circ} \mathrm{E}$ meridian were selected to produce a climatological picture of [Chl $a$ ] fields in spring (March-May; Fig. 4a) and in summer (JuneSeptember; Fig. 4b).

The spring situation (Fig. 4a) displays various types of profiles and a large range of [Chl $a$ ] values. North of $41^{\circ} \mathrm{N}$, [Chl $a$ ] values are high $\left(>1 \mathrm{mg} \mathrm{m}^{-3}\right)$ at the surface and decrease with depth. The highest $[\mathrm{Chl} a]$ values $\left(\sim 3 \mathrm{mg} \mathrm{m}^{-3}\right)$ are observed around $42^{\circ} \mathrm{N}$ at the surface (up to $30 \mathrm{~m}$ depth). Between 40 and $41^{\circ} \mathrm{N}$, surface [Chl $a$ ] is around $0.5 \mathrm{mg} \mathrm{m}^{-3}$ and a DCM is visible at $50 \mathrm{~m}$ depth. Further south, the climatological transect displays a deeper DCM (around $75 \mathrm{~m}$ depth) and very low surface $[\mathrm{Chl} a]$ values $\left(<0.3 \mathrm{mg} \mathrm{m}^{-3}\right)$.

In the summer transect (Fig. 4b), the presence of a DCM is ubiquitous, although its position in the water column and its [Chl $a$ ] values vary throughout the transect. A steady deepening of the DCM is observed from $43^{\circ} \mathrm{N}$ (DCM depth around $50 \mathrm{~m}$ ) to $39^{\circ} \mathrm{N}$ (DCM depth around $85 \mathrm{~m}$ ). A southward decrease in [Chl $a]$ at DCM is also observed. It ranges from 0.8 to $0.4 \mathrm{mg} \mathrm{m}^{-3}$. South of $39^{\circ} \mathrm{N}$, a shallowing of the DCM depth and an increase in the [Chl $a]$ at DCM are observed. 
Table 2. Median and interquartile range (IQR) of [Chl $a]$ at DCM for each geographical location analyzed in Fig. 3 (i.e., yellow diamonds in Fig. 1). Median and IQR were computed by considering all the DCM depth [Chl $a$ ] estimations extracted from available profiles of the $D C M$ standard shape. IQR is the difference between the third and the first quartile.

\begin{tabular}{|c|c|c|c|c|c|c|c|c|c|c|c|c|}
\hline & \multicolumn{3}{|c|}{ Point: $42^{\circ} \mathrm{N}, 5^{\circ} \mathrm{E}$} & \multicolumn{3}{|c|}{ Point: $38^{\circ} \mathrm{N}, 5^{\circ} \mathrm{E}$} & \multicolumn{3}{|c|}{ Point: $36^{\circ} \mathrm{N}, 17^{\circ} \mathrm{E}$} & \multicolumn{3}{|c|}{ Point: $33.5^{\circ} \mathrm{N}, 33^{\circ} \mathrm{E}$} \\
\hline & \multicolumn{3}{|c|}{ (Northwest) } & \multicolumn{3}{|c|}{ (Southwest) } & \multicolumn{3}{|c|}{ (Ionian) } & \multicolumn{3}{|c|}{ (Levantine) } \\
\hline & MEDIAN & IQR & $\mathrm{N}$ & MEDIAN & IQR & $\mathrm{N}$ & MEDIAN & IQR & $\mathrm{N}$ & MEDIAN & IQR & $\mathrm{N}$ \\
\hline Apr & 1.07 & 0.48 & 26 & & & & 0.70 & 0.26 & 107 & 0.47 & 0.09 & 6 \\
\hline May & 0.83 & 0.33 & 38 & 0.97 & 0.23 & 9 & 0.71 & 0.25 & 37 & 0.49 & 0.08 & 6 \\
\hline Jun & 0.97 & 0.36 & 129 & 1.08 & 1.26 & 6 & 0.81 & 0.28 & 17 & 0.37 & 0.25 & 154 \\
\hline Jul & 0.97 & 0.67 & 67 & 0.84 & 0.20 & 160 & 0.42 & 0.23 & 9 & 0.42 & 0.10 & 10 \\
\hline Aug & 0.57 & 0.39 & 45 & 0.73 & 0.36 & 7 & 0.41 & 0.15 & 22 & 0.32 & 0.08 & 11 \\
\hline Sep & 0.63 & 0.21 & 41 & 0.62 & 0.16 & 9 & 0.32 & 0.17 & 23 & 0.32 & 0.06 & 23 \\
\hline Oct & 079 & 0.32 & 33 & 1.06 & 0.11 & 6 & 0.43 & 0.13 & 81 & 0.32 & 0.03 & 10 \\
\hline
\end{tabular}

Table 3. Median value (bold) and first and ninth decile for the following parameters: MLD, euphotic depth $\left(Z_{\mathrm{e}}\right)$, surface [Chl $\left.a\right]$ observed by satellite $\left(\mathrm{Chl}_{\mathrm{SAT}}\right)$ and percentage of chlorophyll content in the upper $20 \mathrm{~m}$ layer compared to the total integrated content $\left(F_{\text {surf }} / F_{T}\right)$.

\begin{tabular}{lrrrr}
\hline & $\begin{array}{r}\text { MLD } \\
(\mathrm{m})\end{array}$ & $\begin{array}{r}Z_{\mathrm{e}} \\
(\mathrm{m})\end{array}$ & $\begin{array}{r}\mathrm{Chl}_{\mathrm{SAT}} \\
\left(\mathrm{mg} \mathrm{m}^{-3}\right)\end{array}$ & $\begin{array}{r}F_{\text {surf }} / F_{\mathrm{T}} \\
(\%)\end{array}$ \\
\hline DCM & $\mathbf{1 4}$ & $\mathbf{7 2}$ & $\mathbf{0 . 1 3}$ & $\mathbf{5 \%}$ \\
& $11-27$ & $57-90$ & $0.05-0.27$ & $2-11$ \\
Modified DCM & $\mathbf{2 6}$ & $\mathbf{5 2}$ & $\mathbf{0 . 3 2}$ & $\mathbf{2 1 \%}$ \\
& $13-52$ & $37-66$ & $0.16-0.63$ & $13-32$ \\
Homogeneous & $\mathbf{8 6}$ & $\mathbf{5 2}$ & $\mathbf{0 . 3 1}$ & $\mathbf{2 1 \%}$ \\
& $27-596$ & $29-71$ & $0.13-1.19$ & $11-43$ \\
Complex & $\mathbf{3 3}$ & $\mathbf{4 8}$ & $\mathbf{0 . 3 6}$ & $\mathbf{2 8 \%}$ \\
& $17-63$ & $33-62$ & $0.18-0.80$ & $18-47$ \\
HSC & $\mathbf{3 5}$ & $\mathbf{3 4}$ & $\mathbf{0 . 7 7}$ & $\mathbf{3 1 \%}$ \\
& $13-95$ & $17-57$ & $0.25-2.76$ & $20-53$ \\
\hline
\end{tabular}

\subsection{Analysis of the profile shapes}

\subsubsection{Characteristics of standard shapes}

As a procedure was established to classify the shapes of the [Chl $a$ ] profiles included in the 1994-2014 database (Sect. 2.3), certain characteristics related to $[\mathrm{Chl} a]$ profiles could be computed. They are summarized in Table 3.

The MLD is shallowest when the standard vertical fluorescence shape is $D C M$. Additionally, the MLD is deepest when the standard florescence shape is homogeneous. In these two cases, the relative position of the MLD and $Z_{\mathrm{e}}$ confirm, therefore, that the homogeneous and DCM shapes can be compared with the well-known stratified and mixed shapes introduced by Morel and Berthon (1989). Profiles shapes categorized as modified DCM, complex and HSC display intermediate values for the MLD. For profiles of the modified DCM shape, the average distance between the MLD and chlorophyll maxima is $22 \mathrm{~m}$. This relatively short distance may indicate that the modified DCM shape derives from erosion by deeper mixing of the DCM structure. For the HSC standard shape, the MLD can be relatively deep (ranging between 13 and $95 \mathrm{~m}$ ). A [Chl $a$ ] gradient could therefore develop in both stratified and mixed conditions. According to Huisman et al. (1999), the development of a [Chl $a]$ gradient in the mixed layer would be possible if mixed layer turbulence were low, thus allowing for the accumulation of phytoplankton cells near the surface.

According to the results presented in Table 3, ocean color surface $[\mathrm{Chl} a$ ] values are related to the shape of the vertical profile. The lowest surface [Chl $a]$ values are observed for $D C M$ shape profiles, while the highest $\left(0.77 \mathrm{mg} \mathrm{m}^{-3}\right)$ values are observed for $H S C$ shape profiles. In spite of its variability, this high value suggests that the HSC shape could result from the exponential growth of phytoplankton at the surface in unlimited-nutrient conditions associated with a stable water column. Hence, HSC profiles would typically correspond to bloom conditions. A very high variability, with surface [Chl $a$ ] values ranging from 0.13 to $1.19 \mathrm{mg} \mathrm{m}^{-3}$, is observed for profiles of the standard homogeneous shape. This variability likely results from the interactions between the high variability in the MLD and the recent development of phytoplankton biomass.

The $F_{\text {surf }} / F_{\mathrm{T}}$ ratio changes with the shape of the [Chl $a$ ] profile. The lowest ratio (5\%) is observed for the $D C M$ shape, even though this value is likely to be underestimated by a factor of 2.5 because of NPQ. The standard complex and $H S C$ shapes display similar median ratios: 28 and $31 \%$, respectively. Once again, there is a large variability among homogeneous shape profiles that which can be explained by the variability in the MLD. Finally, in the HSC situation, the upper $20 \mathrm{~m}$ can accumulate up to $50 \%$ of the chlorophyll content. 


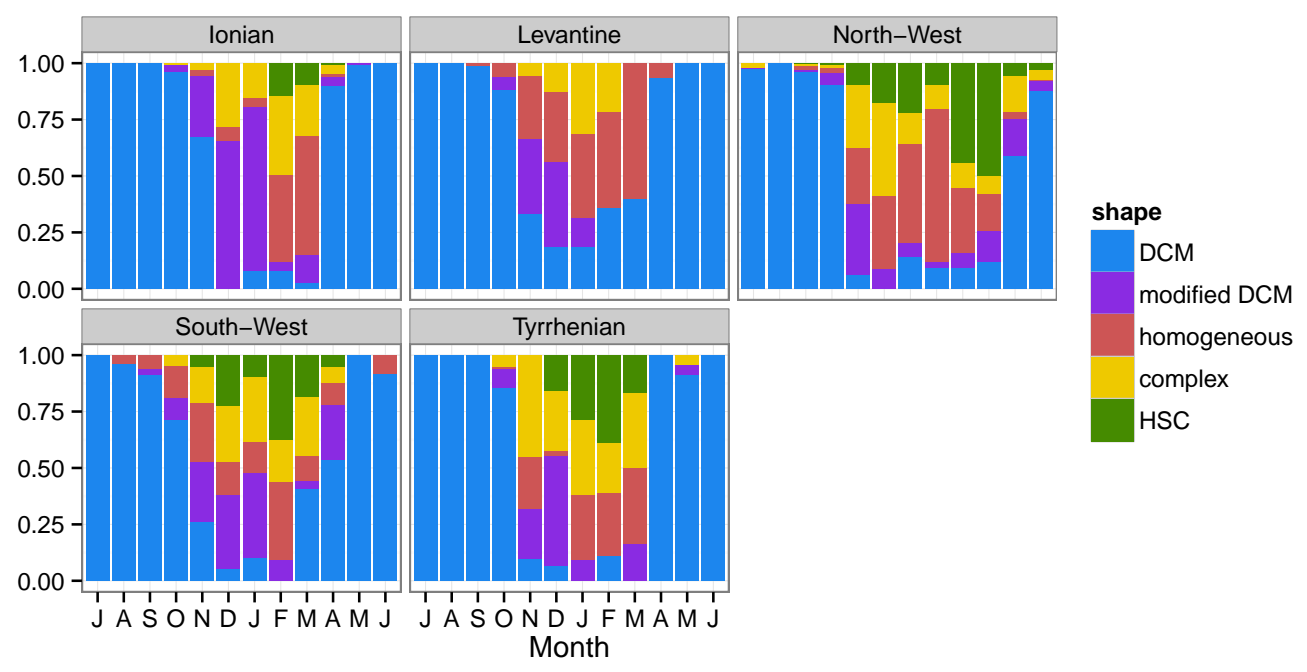

Figure 5. Histograms indicating for each month and each Mediterranean region the proportion of each type of standard shape observed in the 1994-2014 database (i.e., DCM, homogeneous, HSC, modified DCM and complex; see Fig. 2 and Sect. 2.3). The height of color bars indicates the proportion of profiles which were classed in each category of standard shapes. Note that months range from July to June.

\subsubsection{Seasonal distribution of the profile shapes}

A study of the seasonal distributions of standard shapes was performed for the main Mediterranean regions (Fig. 5, boundaries of the Mediterranean regions are drawn in Fig. 1). During summer, all the regions are dominated by the $D C M$ shape, with occurrences exceeding $90 \%$. The DCM shape disappears everywhere in November. The time of its onset depends on the region: it occurs in April in the Ionian, Levantine and Tyrrhenian regions, in May in the southwest region, and in June in the northwest region. During the autumn and winter period, all the categories of shapes can be observed in the same region and during the same month. Nevertheless, profiles shapes classed as modified DCM are more frequent in early winter (i.e., in the Ionian region where the modified DCM shape represents more than $60 \%$ of profiles in December and January), which reinforces the impression that this shape may be generated by deeper mixing eroding the DCM structure. Profiles with the homogeneous shape are observed everywhere from November to March, except in the Ionian region. Similarly, the complex shape is present everywhere from November to March. Profiles displaying an HSC shape are absent, or nearly absent, in the Ionian and Levantine regions. In the Tyrrhenian and southwest regions, HSC profiles can be observed between November and March and are most abundant in February. In the northwest region, although $H S C$ profiles are observed in winter from November to February, they peak in spring (March-April), with occurrences exceeding $60 \%$. Assuming that the $H S C$ profiles denote bloom events, this result suggests that bloom events may occur during winter in the whole western Mediterranean although they only peak in the northwest region during spring.
Table 4. Regional average values and standard deviations (numbers in brackets) for a set of parameters. The winter MLD was computed with January and February MLDs. The DCM depth and the PAR (photosynthetically active radiation) at DCM has been computed only for profiles belonging to the DCM standard shape category. PAR at DCM has been determined for each fully calibrated (i.e., 1998-2014 database) [Chl $a$ ] vertical profiles. The vertical profile of the PAR attenuation coefficient was computed from [Chl $a$ ] vertical profiles and applied to surface PAR estimates derived from the monthly SeaWiFS PAR climatology. For the nitracline depth, the isoline $1 \mu \mathrm{M}$ was computed on a large set of nitrates profiles derived from MEDAR and SESAME programs (see Lavigne et al., 2013 , for details about their database).

\begin{tabular}{lrrrr}
\hline & $\begin{array}{r}\text { Winter } \\
\text { MLD } \\
(\mathrm{m})\end{array}$ & $\begin{array}{r}\text { Nitracline } \\
\text { depth } \\
(\mathrm{m})\end{array}$ & $\begin{array}{r}\text { DCM } \\
\text { depth } \\
(\mathrm{m})\end{array}$ & $\begin{array}{r}\text { PAR at DCM } \\
\left(\text { mol photons m }^{-2}\right. \\
\left.\text { day }^{-1}\right)\end{array}$ \\
\hline Northwest & $342(623)$ & $62(38)$ & $51.7(12.5)$ & $1.03(0.86)$ \\
Southwest & $47(63)$ & $78(24)$ & $73(17)$ & $0.77(0.77)$ \\
Tyrrhenian & $45(38)$ & $97(23)$ & $73(13)$ & $0.57(0.19)$ \\
Adriatic & $126(181)$ & $56(24)$ & $56(10)$ & - \\
Ionian & $67(46)$ & $119(46)$ & $83(29)$ & $0.51(0.64)$ \\
Levantine & $122(122)$ & $185(47)$ & $102(17)$ & $0.16(0.16)$ \\
\hline
\end{tabular}

\subsubsection{Longitudinal and seasonal distribution of the DCM depth}

The DCM is confirmed to be a dominant feature of the $[\mathrm{Chl} a]$ distribution in the Mediterranean, although its characteristics change from one region to another and with time. A deepening of the DCM depth with longitude is generally observed (Fig. 6), confirming previous findings (Crise et al., 1999). A linear model applied to DCM depth data indicates that, on average, DCM depth deepens by $1.6 \mathrm{~m}$ for $1^{\circ}$ of longitude. However, large variability exists, especially in the Io- 


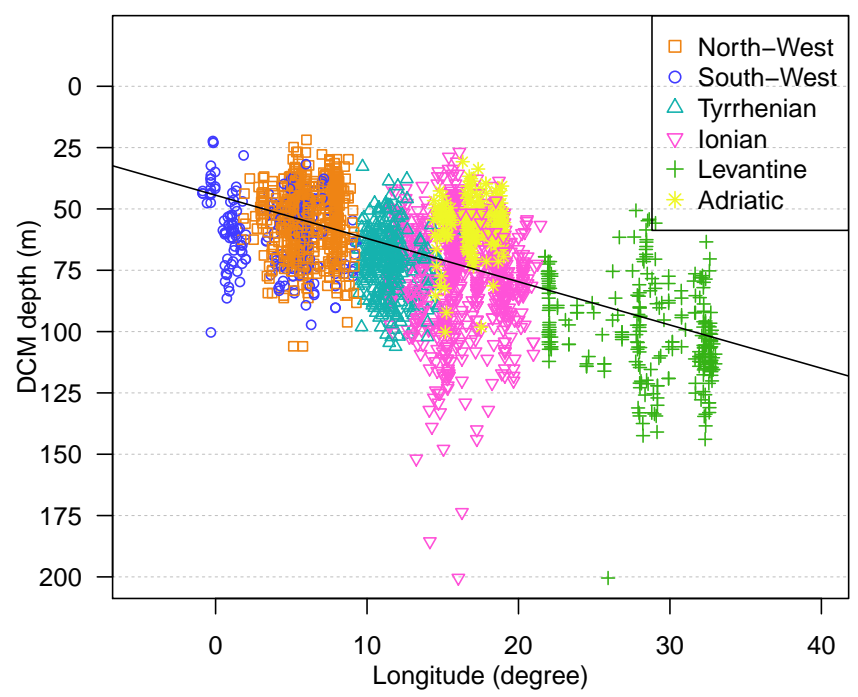

Figure 6. DCM depth as a function of longitude. DCM depths were computed only on profiles of the DCM standard shape (see Sect. 2.3 for an objective definition of $D C M$ shape). Black line represents the linear model between the DCM depth and the longitude. Its slope is $1.6 \mathrm{~m}$ per degree of longitude.

nian and Levantine seas. Superimposed on this general deepening of DCM with longitude, regional differences can be observed between the main Mediterranean subbasins. Considering profiles at the same range of longitude, the averaged DCM depth is deeper and more variable in the southwest region than in the northwest region (see Table 4). In the eastern basin, the Adriatic region displays shallow and stable DCM depths, whereas the Ionian and Levantine regions display deeper and more variable DCM depths (Table 4).

Part of the variability observed in the different Mediterranean regions can be explained by seasonality. All the Mediterranean regions have a seasonal variability in the DCM depth (Fig. 7), which is characterized by a widespread deepening from March to midsummer and a shallowing from midsummer to November. In all the Mediterranean regions, except the northwest region, there is a $40 \%$ deepening of the DCM between spring and summer (33\% in the northwest).

\section{Discussion}

\subsection{Methodological discussion}

\subsubsection{Comparison with MEDATLAS}

The climatological profiles for each of the four geographical points analyzed in Sect. 3.1 have been computed from the MEDATLAS climatology and compared to their fluorescence-based counterparts evaluated here (Fig. 8). For each geographical point, the two versions of [Chl $a$ ] vertical profiles (fluorescence-based and MEDATLAS) displayed similar ranges of values, although differences are observed in

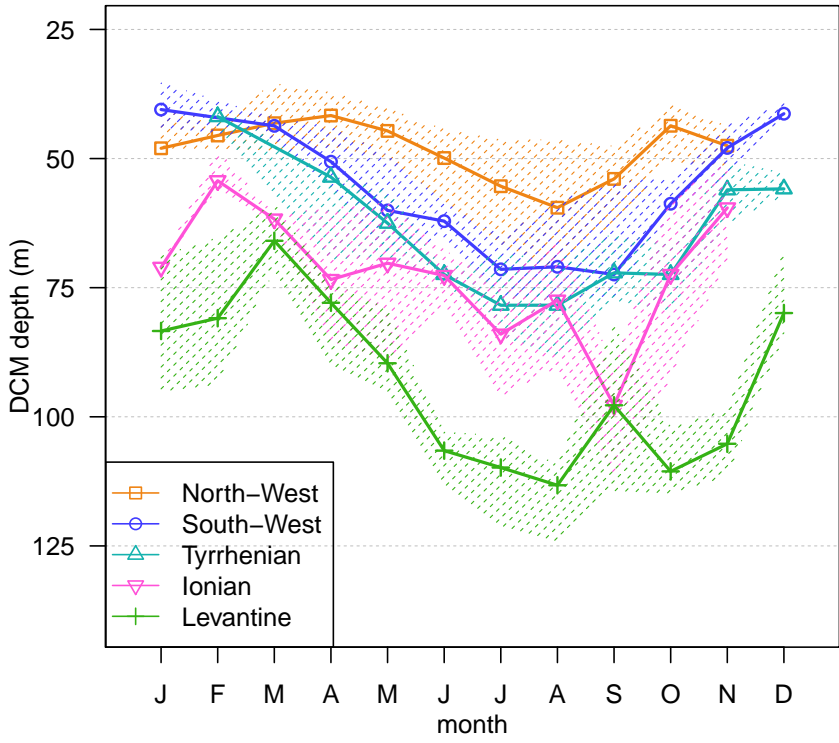

Figure 7. Seasonal evolution of the DCM depth. DCM depths were computed only on profiles of the $D C M$ standard shape (see Sect. 2.3 for an objective definition of $D C M$ shape). Symbols refer to monthly median, whereas dotted areas indicate the interquartile range.

the form of [Chl $a$ ] vertical profiles. The fluorescence-based profiles often display thinner DCMs with higher [Chl $a$ ] values than in the MEDATLAS climatology (see, for instance, Fig. $8 \mathrm{~b}$ for summer, c for autumn and $\mathrm{d}$ for summer). Moreover, in the MEDATLAS climatology, very weak seasonal changes in the DCM depth are visible. These divergences can be explained by the use of discrete data and of interpolation in the MEDATLAS climatology, which prevents the proper characterization of vertical structures. In winter, the MEDATLAS climatology, and sometimes the fluorescencebased climatology, shows profiles with subsurface maxima (Fig. 8a, b, c, winter), which have not been observed in the monthly fluorescence-based time series (Fig. 3). We hypothesize that these winter subsurface maxima could be an artifact caused by the large averaging timescale (from December to March), leading to the combination of [Chl $a$ ] profiles with highly different vertical distributions (see Fig. 5). Another particular feature of the MEDATLAS climatology that does not show in the fluorescence-based climatology is represented by the rises in summer and autumn surface [Chl $a$ ] above DCM (Fig. 8a, b and d). We suggest that this feature could result from the propagation by interpolation of the high surface [Chl $a$ ] observed on coastal regions (see also Bosc et al., 2004). In addition, considering the geographical positions of the available MEDAR observations, in almost all the studied subbasins (except Ionian), coastal observations are included in the database. They might therefore be responsible for the observed difference with the fluorescence-based climatology. 

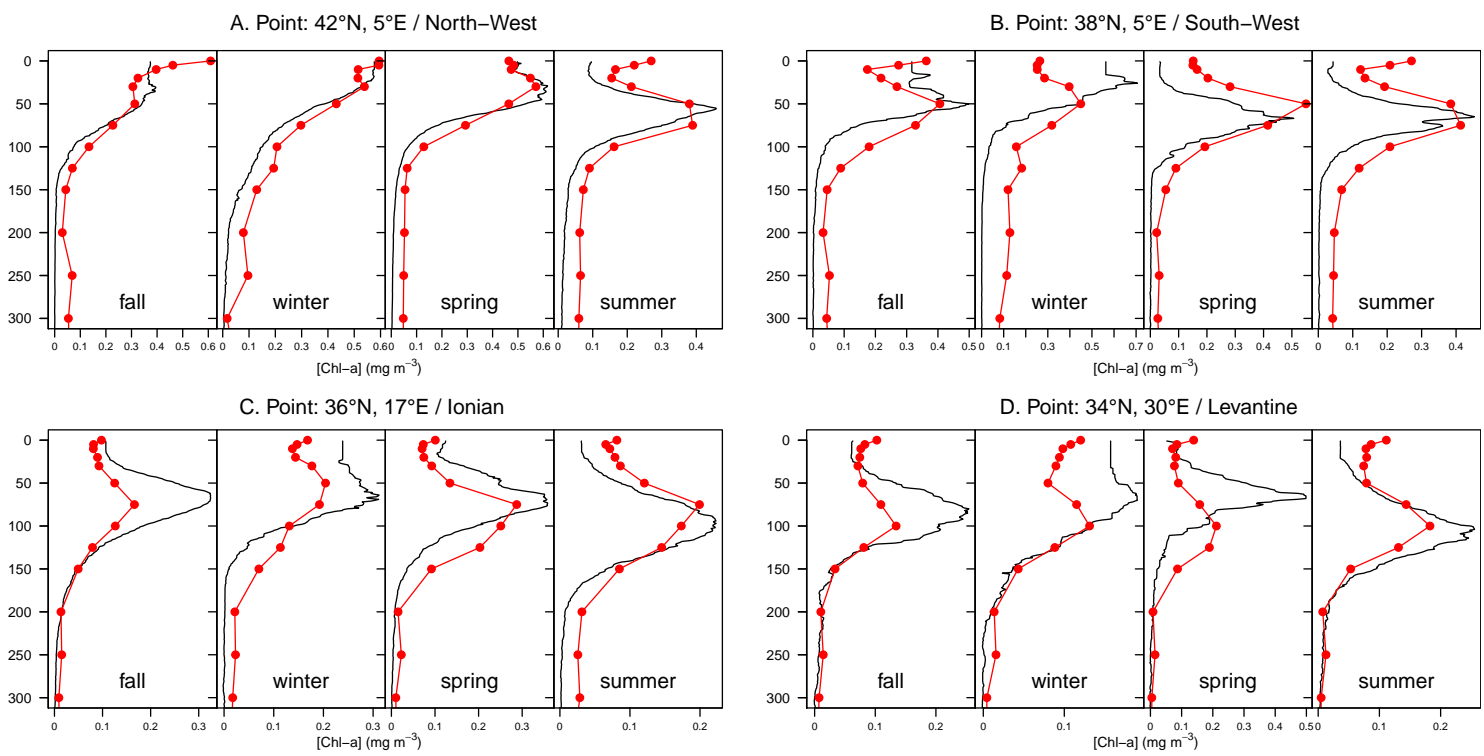

Figure 8. [Chl $a$ ] profiles obtained from the MEDATLAS climatology for the four locations analyzed in Fig. 3 (red lines and red points). MEDATLAS climatology was downloaded from http://modb.oce.ulg.ac.be/backup/medar/medar_med.html. For comparison, corresponding seasonally averaged profiles were computed from the 1998-2014 [Chl $a$ ] fluorescence database (black lines). Seasons are calendar-based seasons.

In summary, the results of this comparison demonstrate that, although the MEDATLAS database is extremely valuable, the derived MEDATLAS fields for [Chl $a$ ] present serious limitations, and they need to be updated.

\subsubsection{Methodological approaches}

In the present study, two different approaches have been used to describe the monthly variability in [Chl $a$ ] profiles. On one hand, the standard method consists of averaging [Chl $a$ ] values for a number of defined standard depths (i.e., Conkright et al., 2002; Sect. 3.1). On the other hand, a "probabilistic" method (Sect. 3.2), for which each [Chl $a$ ] profile is considered as a whole, focuses the analysis on each profile's general shape and on specific features (e.g., DCM depth). The second approach requires an a priori knowledge of the different profile shapes found in the database as well as the definition of an efficient and automatic procedure to categorize the profiles. In this analysis, the main standard shapes and the classification procedure were defined after individual visualization of all the fluorescence profiles in the database and the determination of their characteristics (i.e., $D_{\max }, F_{\mathrm{MLD}} / F_{\mathrm{T}}$, $F_{\text {max }} / F_{\text {surf }}$; see Sect. 2.3 for details).

These two approaches are complementary. The standard method highlights the average pattern of the $[\mathrm{Chl} a]$ profile and provides the ranges of [Chl $a$ ] values. However, [Chl $a$ ] values must be considered independently for each depth, and the shape of the resulting climatological profile has to be interpreted carefully because it is a composite. A typical artifact of this method is the tendency of the DCM to be flattened (compare the DCM of Fig. 3 and the values in Table 2).
In these cases (i.e., [Chl $a$ ] profile extremely stable, as during summer, or very dynamic, as during winter), the probabilistic analysis of the shape of the [Chl $a$ ] profile appears more pertinent. In addition, the probabilistic analysis provides information on the environmental processes that lead to the observed [Chl $a$ ] shape. As mentioned in Sect. 3.2.1, the modified DCM shape likely results from the erosion by upper vertical mixing of the DCM structure, while the homogeneous standard shape is likely driven by vertical mixing, which encompasses the whole [Chl $a$ ] profile. Similarly, the $H S C$ profiles, associated with high surface [Chl $a$ ] values (see Table 3), could be collected (and then associated with) during surface phytoplankton bloom conditions. Under these conditions, if there is no nutrient limitation, growth rate is essentially affected by light availability and then decreases with depth. This can account for the derived decrease in the $[\mathrm{Chl} a]$ gradient from surface to depth. Nevertheless, these conjectures have to be considered on a statistical basis. Indeed, each individual profile is affected by complex and variable factors (i.e., vertical mixing, 3D dynamic structures, light distribution, grazing pressure; see Longhurst and Harrison, 1989, and see also discussion below), which sometimes lead to erratic [Chl $a$ ] vertical distributions that become difficult to explain (17\% of profiles have been classed as complex standard shapes). Finally, the probabilistic analysis also revealed that seasonal changes in $[\mathrm{Chl} a]$ profiles are not smooth and steady, as the climatological analysis may suggest, but rather are extremely variable. 


\subsection{A new vision of the $[\mathrm{Chl} a]$ in the Mediterranean Sea}

\subsubsection{Comparison with satellite ocean color observations}

The main feature that emerges from the analysis of annual cycles of surface $[\mathrm{Chl} a]$ from ocean color data over the Mediterranean sea is the coexistence of two main types of cycle (Bosc et al., 2004; D’Ortenzio and Ribera 2009; Lavigne et al., 2013). The two cycles ("NO BLOOM" and BLOOM", following the definition of D'Ortenzio and Ribera d'Alcalà, 2009) can be characterized, firstly, by a 2 -fold increase from summer to winter in the normalized [Chl $a$ ] (so-called NO BLOOM annual cycle) and, secondly, by a moderate (2fold) increase in normalized [Chl $a$ ] from summer to winter, followed by an exponential increase (3-fold) in early spring (so-called BLOOM annual cycle). These findings are based on satellite surface $[\mathrm{Chl} a]$ and result from a complex statistical analysis (i.e., normalization of the seasonal cycles and clustering analysis), but they have also been confirmed by the climatological time series presented here (see Sect. 3.1). Climatologies of [Chl $a$ ] profiles (Fig. 3) for the southwestern region (Fig. 3b), the Ionian region (Fig. 3c) and the Levantine region (Fig. 3d), which correspond to the NO BLOOM regions identified by D'Ortenzio and Ribera d'Alcalà (2009), display similarities in the seasonal variations in surface [Chl $a$ ], and they also showed a similar succession of winter homogeneous profiles and summer profiles with DCM. In contrast, the time series corresponding to the northwestern region (Fig. 3a) presents, in March and April, $[\mathrm{Chl} a]$ vertical profiles characterized by high surface concentrations (i.e., HSC profiles), confirming the specific feature of the northwestern region in the Mediterranean Sea. Unlike NO BLOOM Mediterranean regions, in the northwest region, the average winter MLD is deeper than the DCM and the nitracline depth (see Table 4). This particularity explains the March-April bloom, which could be supported by large winter nutrient supplies and/or the dilution of grazers. It also indicates that winter vertical mixing fully destroys the nitracline, pycnocline and DCM, which have to be restored each year. The annual renewal of these structures contributes to their tight coupling (see Fig. 3a and Table 4), which is not observed in NO BLOOM Mediterranean regions (based on the results in Fig. 3, DCM and pycnocline are uncoupled). In NO BLOOM regions, except for extreme MLD events (Lavigne et al., 2013), the winter MLD does not generally reach the depths reached by the DCM and nitracline during summer (see Table 4).

Beyond the bimodal conception (i.e., BLOOM/NO BLOOM) of annual [Chl $a$ ] cycles in the Mediterranean Sea, there is an important and unresolved complexity marked by the presence of regional differences within the two main biomass annual cycles. A good illustration of this complexity is the identification by D'Ortenzio and Ribera
d'Alcalà (2009) of three different annual cycles (i.e., three bioregions) for the NO BLOOM dynamics. The probabilistic analysis of the general shape of the $[\mathrm{Chl} a]$ profiles performed in this paper also contributes to refining the basic BLOOM/NO BLOOM scheme and should help to explain the complex patterns observed at the surface. In Fig. 5, regional differences in the distribution of the standard shapes for [Chl $a$ ] vertical profiles are observed among the NO BLOOM regions (i.e., southwest, Levantine and Ionian regions). The main difference is the significant proportion of $H S C$ profiles during the winter months (i.e., January, February and March) in the southwest region, whereas this proportion is very small (less than $10 \%$ ) in the Ionian sea and even 0 in the Levantine Sea. The observation of HSC profiles in the southwest region suggests that, during winter, mixing is able to supply enough nutrients at the surface to support episodic development of phytoplankton close to the surface when the water column begins to stabilize. This could also explain the higher [ $\mathrm{Chl} a$ ] observed in the southwest region and the difference between the southwestern and eastern normalized [Chl $a$ ] annual cycles (D'Ortenzio and Ribera d'Alcalà, 2009). Compared to the eastern Mediterranean Sea, DCM and nitracline depths are shallow in the southwest region (Table 4). However, winter mixing is constrained, in the Algerian Basin, by the strong halocline associated with the spreading of Atlantic Water, and barely reaches the nitracline depth (D'Ortenzio and Prieur, 2012; Lavigne et al., 2013). As sub-mesoscale activity, associated with jets, fronts and eddies, is also similarly intense in both the southwestern and eastern basin (Rio et al., 2007), our best explanation for the spatial divergences in the occurrence of $H S C$ profiles is the regional difference in nutrient stocks below the nitracline. Indeed, for the intermediate layer, the nitrate concentration is much higher in the western than in the eastern basin (Ribera d'Alcalà et al., 2003). In addition, the nitrateto-phosphate ratio increases eastward, suggesting that phytoplankton growth is mainly limited by phosphate in the eastern Mediterranean Sea (Ribera d'Alcalà et al., 2003; Béthoux et al., 2002; Krom et al., 1991). Hence, the absence of HSC profiles in the eastern Mediterranean Sea could be due to a weak mixing efficiency that is not sufficient to support a phytoplankton bloom.

\subsubsection{High diversity of the Mediterranean [Chl $a]$}

Although the Mediterranean Sea covers a relatively small latitudinal range (from 30 to $45^{\circ} \mathrm{N}$ ), previous findings, essentially based on satellite observations, have shown that in this basin, the annual phytoplankton cycles representative of subtropical and midlatitude regions of the global ocean coexist (D'Ortenzio and Ribera d'Alcalà, 2009; Lavigne et al., 2013). Present results, which focus on the seasonal variability in the whole [Chl $a$ ] vertical distribution, confirm these previous statements. The climatological time series of [Chl $a]$ profiles (Fig. 3) for the southwestern region (Fig. 3b), 
the Ionian region (Fig. 3c) and the Levantine region (Fig. 3d) are very close to typical subtropical behavior, marked by the quasi-permanent existence of the DCM (Letelier et al., 2004; Mignot et al., 2014). In particular, the [Chl $a$ ] climatology of the BATS (Bermuda Atlantic Time-series Study) station in the subtropical North Atlantic gyre (Steinberg et al., 2001; Lavigne et al., 2012) displays many similarities, in terms of ranges of values for [Chl $a$ ], DCM depths and winter mixing depths, with the climatological time series built in the Levantine Sea (Fig. 3d). The only main difference is that the homogeneous climatological profiles begin in December in the Mediterranean regions and only in January at the BATS station (Lavigne et al., 2012). Regarding seasonal cycles obtained for the northwestern Mediterranean Sea, they can be easily compared to midlatitude $\left(40^{\circ}-60^{\circ}\right)$ regions marked by an intense spring bloom as in the North Atlantic (Siegel et al., 2002) or in certain regions of the Southern Ocean (Thomalla et al., 2011). Similarly to our northwestern Mediterranean observations, the seasonal cycles for [Chl $a$ ] vertical profiles presented by Boss et al. (2008) in the western North Atlantic (about $50^{\circ} \mathrm{N}$ ) and by Chiswell (2011) in the waters east of New Zealand (about $40^{\circ} \mathrm{S}$ ) display a majority of profiles with a homogeneous shape during winter and, in spring, a predominance of profiles displaying an HSC shape or a homogeneous shape with high $[\mathrm{Chl} a]$ values. The coexistence of profiles with homogeneous and HSC shapes during spring could be explained by the intermittent feature of mixing, which continuously modifies the vertical distribution of [Chl $a$ ] during the spring bloom (Chiswell, 2011). Finally, it is important to mention that the summer situation is very different between the North Atlantic region studied by Boss et al. (2008) and the northwestern Mediterranean Sea. Although DCM profiles are nearly permanent in the northwestern Mediterranean from May or June, Boss et al. (2008) only observed them to start in late summer.

The present study also shows that in the Mediterranean Sea, the specific features of the $[\mathrm{Chl} a]$ profiles with a $D C M$ shape have large variability, comparable to those observed in the global ocean, although occurring on shorter spatial scales. The most relevant indicator is certainly the DCM depth, which was observed to range between $30 \mathrm{~m}$ and more than $150 \mathrm{~m}$. As expected (e.g., Cullen, 2015), the depth of the Mediterranean DCM is inversely related to the surface [Ch $a$ ] (Fig. 9). In addition, the relationship between the DCM depth and surface $[\mathrm{Chl} a]$ (blue curve in Fig. 9) is similar to the relationship reported for the global ocean (red curve in Fig. 9; Mignot et al., 2011). This observation suggests that certain DCM properties in the Mediterranean Sea conform to the same generic properties established for the global ocean.

At the first order, the DCM depth variability in the Mediterranean Sea is related to the spatial component and, in particular, longitude. The deepening of the DCM along a longitudinal gradient (in the present study, DCM deepens by $1.6 \mathrm{~m}$ per 1 degree of longitude east) agrees with the previous review, also based on observations, by Crise et al. (1999).

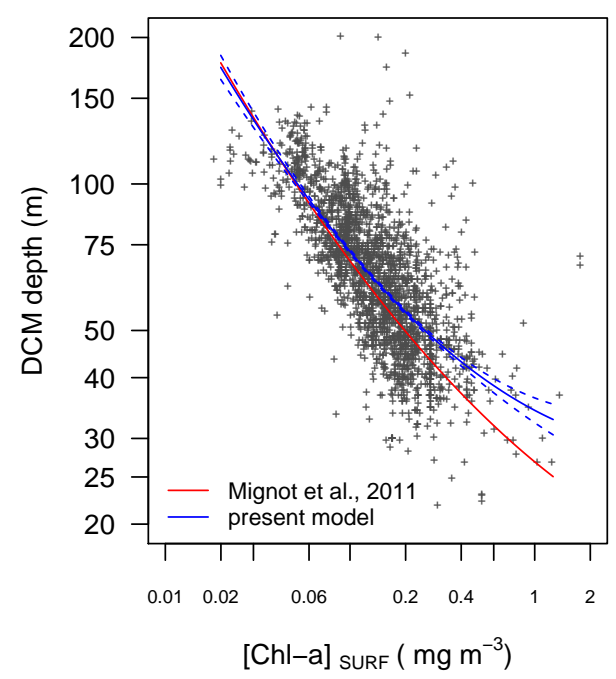

Figure 9. Scatter of the DCM depth as a function of surface [Chl $a$ ]. Only profiles of the DCM standard shape were used for this analysis. Surface [Chl $a$ ] were obtained from satellite ocean color data. The blue solid line represents a second-order polynomial model determined from present data $\left(R^{2}=0.52\right)$ with its confidence intervals (blue dotted lines), and the red line represents the model computed by Mignot et al. (2011) from a global ocean data set.

This general deepening of the DCM with longitude covaries with the eastward increase in oligotrophy in the Mediterranean Sea (Béthoux et al., 1998). This pattern is generally attributed to anti-estuarine circulations in the Straits of Gibraltar and Sicily, which generate an eastward inflow of surface nutrient-depleted waters and a westward outflow of deep nutrient-rich waters. In the eastern Mediterranean Sea, oligotrophy is also maintained by poor nutrient inputs from the boundaries (atmosphere and coasts) and by the formation of Levantine Intermediate Water, which is not the product of deep convection but of the subduction of surface water into intermediate water layers (Robinson and Golnaraghi, 1994). As revealed by Table 4, regional changes in DCM depth, nitracline depth and averaged daily PAR at DCM are correlated in the Mediterranean Sea. The eastward deepening of the DCM depth and of the nitracline depth is accompanied by a decrease in the mean daily averaged PAR at DCM (values ranging from $1 \mathrm{~mol}$ quanta $\mathrm{m}^{-2} \mathrm{day}^{-1}$ in the northwest Mediterranean to $0.16 \mathrm{~mol}_{\text {quanta }} \mathrm{m}^{-2}$ day $^{-1}$ in the Levantine Sea). This trend agrees with the "general rule" that states that the DCM builds up where there is an optimal balance between the upward nutrient flux and the downward photon flux and lies on top of the nutricline (Cullen, 2015). The large distance between DCM depth and nitracline depth in the Ionian $(36 \mathrm{~m})$ and the Levantine ( $83 \mathrm{~m}$ ) basins may be considered as contradicting the previous theory. However, as can be seen in Table 4, the estimations of nitracline depth are not likely to be good estimators of the top of the nitracline if the nitrate gradient is not sharp enough, as is the case, for example, in 

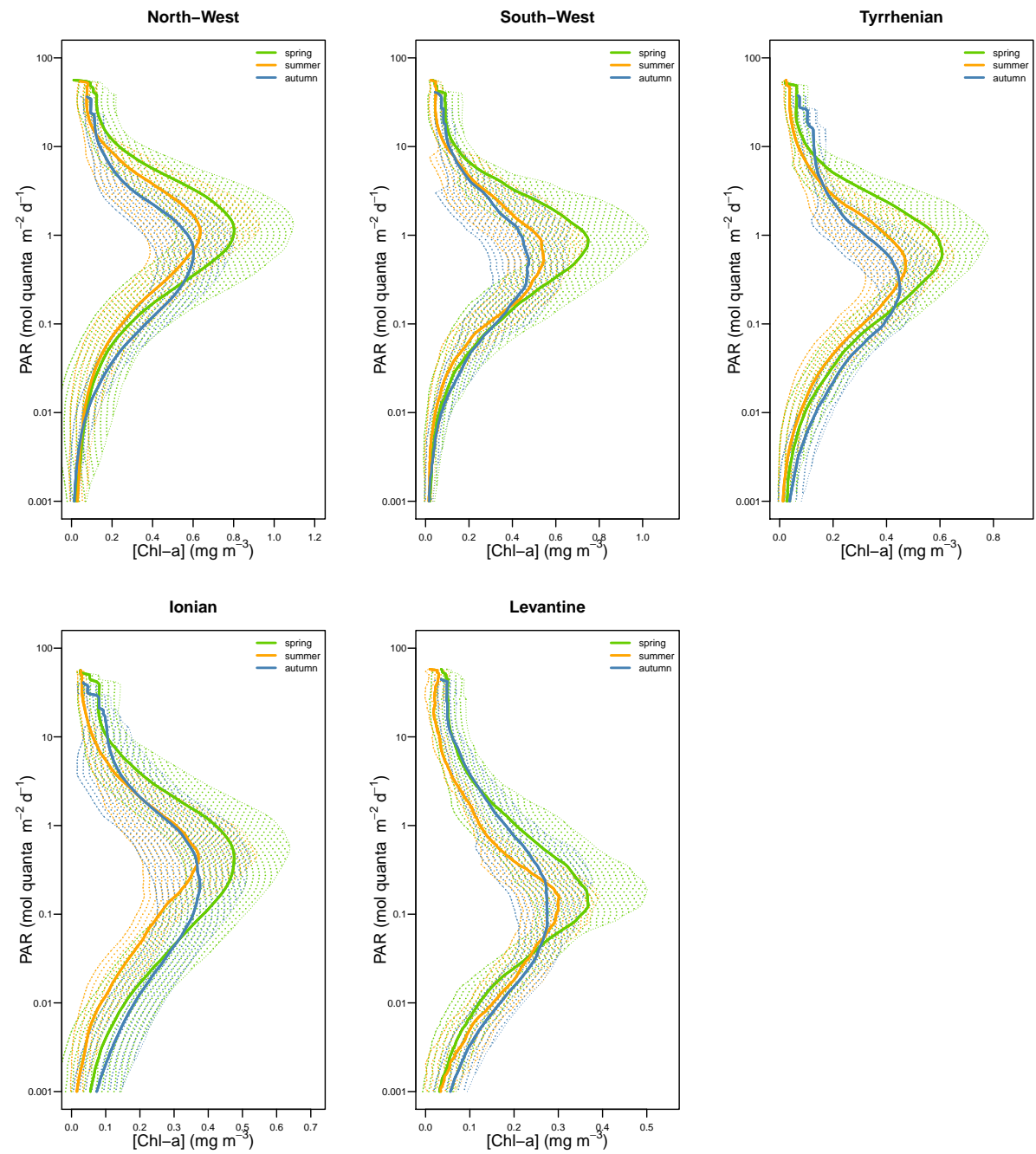

Figure 10. Averaged vertical distribution of [Chl $a$ ] as a function of PAR with standard deviation (dotted area). Spring refers to the April-June period, summer to July and August, and autumn to the September-November period.

the eastern Mediterranean Sea. Indeed, nitracline depths have been computed from discrete vertical profiles, using the $1 \mu \mathrm{M}$ isoline (Lavigne et al., 2013).

The results in Fig. 10 also show that a seasonal component contributes to explaining DCM variability in the Mediterranean regions. The observed seasonal pattern of the DCM depth (i.e., deepening from spring to summer and shallowing from summer to autumn) is consistent with previous model results (Macias et al., 2014) and with individual Bio-Argo float observations (Mignot et al., 2014). Letelier et al. (2004) and Mignot et al. (2014) explain this seasonal pattern by considering that the DCM depth might be driven by the light availability and that it would follow the depth of an isolume. This observation is confirmed here by the analysis of the vertical $[\mathrm{Chl} a$ ] profile as a function of irradiance for the spring, summer and autumn periods (Fig. 10). For all regions, from spring to summer, PAR at DCM depth remains unchanged although $[\mathrm{Chl} a]$ decreases. Accordingly to Lete- lier et al. (2004), higher spring [Chl $a]$ may be explained by the temporal erosion of the upper nitracline from spring to summer, supporting the hypothesis of deep biomass maxima. From summer to autumn, the magnitude of DCMs remains roughly unchanged, similarly to the PAR at DCM.

\section{Conclusions}

Since the initial work of the MEDAR/MEDATLAS group (Maillard et al., 2005; Manca et al., 2004), the proposed study represents the first attempt to analyze the seasonal variations in the $[\mathrm{Chl} a]$ vertical distribution over the Mediterranean Sea. The picture of the [Chl $a$ ] field in the basin has been updated here, as it had been mainly derived from surface satellite data or from limited and scarce in situ observations. Chlorophyll $a$ fluorescence data (specifically calibrated and consistently processed with a dedicated method) provided a significantly larger database than the commonly 
used in situ bottle estimations. Additionally, a better description of the vertical distribution was made possible. In order to carry out a comprehensive analysis of the seasonal variability in the vertical $[\mathrm{Chl} a$ ] profiles within the main Mediterranean subbasins, 6790 profiles of fluorescence were gathered and processed. The present analysis, in agreement with previous satellite results (D'Ortenzio and Ribera d'Alcalà, 2009), demonstrates the coexistence of two main types of dynamics (i.e., subtropical and midlatitude dynamics) in the Mediterranean Sea. Midlatitude dynamics are observed in the northwestern basin. Their main specificity is the high occurrence of $H S C$ profiles in March and April, whereas this type of shape, associated with bloom conditions, is nearly absent elsewhere during this season. The subtropical dynamics encompass most of the remaining basin. They are characterized by an omnipresent DCM from spring to autumn and by a large variety of $[\mathrm{Chl} a]$ vertical shapes during winter. The present analysis also demonstrated that the $[\mathrm{Chl} a]$ pattern in the Mediterranean Sea is not uniform. Even among regions with subtropical dynamics, a strong variability was observed in [Chl $a$ ] values or DCM characteristics. On the basin scale, this variability follows an eastward oligotrophic pattern.

The present study was often limited by the quantity of data, which did not allow for the analysis of each region of the Mediterranean Sea (e.g., the Adriatic Sea). We regret the singular absence of fluorescence profiles in oceanographic databases compared to other parameters. For instance, in the MEDAR database, there are 118009 salinity profiles, 44928 oxygen profiles and only 1984 chlorophyll $a$ fluorescence profiles. Finally, in this study we were only able to present climatological behavior. Although it is a first and necessary step for a better understanding of processes which impact seasonal variability in $[\mathrm{Chl} a]$ vertical profiles, it would be interesting to further study certain particular cases showing, with a high-frequency, annual series of vertical $[\mathrm{Chl} a]$ profiles. These data have now become available with the development of Bio-Argo floats (Johnson et al., 2009) and some studies have already demonstrated their potential for such applications (Boss and Behrenfeld, 2010; Mignot et al., 2014).

Acknowledgements. The authors would like to thank all people involved in the collection and distribution of the oceanographic data used in this paper. We thank PANGAEA, SISMER, the National Oceanographic Data Center and the OGS data center for making data freely available online. The programs LEFE-CYBER, Bio-Argo, MEDAR and IP SESAME are thanked for their valuable contribution to Mediterranean databases. The US NASA Agency is thanked for the easy access to SeaWiFS and MODIS data. We acknowledge the support of the European Commission (Cofunded by the European Union under FP7 - People - Co-funding of Regional, National and International Programmes, GA no. 600407) and of the RITMARE Flagship Project. This work is also the contribution to the PABO (Plateformes Autonomes and Biogeochimie Oceanique), funded by the ANR, to the French "Equipement d'Avenir" NAOS project (ANR J11R107-F) and to the remotely
Sensed Biogeochemical Cycles in the Ocean (remOcean) project, funded by the European Research Council (grant agreement 246777). We are also grateful to Louis Prieur, Josephine Ras and Julia Uitz for constructive comments and suggestions.

Edited by: E. Boss

\section{References}

Andersen, V. and Prieur, L.: One-month study in the open nw mediterranean sea (dynaproc experiment, may 1995): overview of the hydrobiogeochemical structures and effects of wind events, Deep Sea Res. Pt. I, 47, 397-422, 2000.

Antoine, D., Morel, A., and André, J.-M.: Algal pigment distribution and primary production in the eastern Mediterranean as derived from coastal zone color scanner observations, J. Geophys. Res., 100, 16193-16209, 1995.

Barale, V., Jaquet, J.-M., and Ndiaye, M.: Algal blooming patterns and anomalies in the Mediterranean Sea as derived from the SeaWiFS data set (1998-2003), Remote Sens. Environ., 112, 33003313, 2008.

Béthoux, J., Morin, P., Chaumery, C., Connan, O., Gentili, B., and Ruiz-Pino, D.: Nutrients in the Mediterranean Sea, mass balance and statistical analysis of concentrations with respect to environmental change, Mar. Chem., 63, 155-169, 1998.

Béthoux, J. P., Morin, P., and Ruiz-Pino, D. P.: Temporal trends in nutrient ratios: chemical evidence of Mediterranean ecosystem changes driven by human activity, Deep Sea Res. Pt. II, 49, 2007-2016, 2002.

Biermann, L., Guinet, C., Bester, M., Brierley, A., and Boehme, L.: An optimised method for correcting quenched fluorescence yield, Ocean Sci. Discuss., 11, 1243-1264, doi:10.5194/osd-111243-2014, 2014.

Bosc, E., Bricaud, A., and Antoine, D.: Seasonal and interannual variability in algal biomass and primary production in the Mediterranean Sea, as derived from 4 years of SeaWiFS observations, Global Biogeochem. Cy., 18, 1-17, 2004.

Boss, E. and Behrenfeld, M.: In situ evaluation of the initiation of the North Atlantic phytoplankton bloom, Geophys. Res. Lett., 37, L18603, doi:10.1029/2010GL044174, 2010.

Boss, E., Swift, D., Taylor, L., Brickley, P., Zaneveld, R., Riser, S., Perry, M., and Strutton, P.: Observations of pigment and particle distributions in the western North Atlantic from an autonomous float and ocean color satellite, Limnol. Oceanogr., 53, 21122122, 2008.

Boyer, T. P., Antonov, J. I., Baranova, O. K., Carla, C., Garcia, H. E., Grodsky, A., Johnson, D. R., Locarnini, R. A., Mishonov, A. V., O'Brien, T. D., Paver, C. R., Reagan, J. R., Seidov, D., Smolyar, I. V., and Zwengan, M. M.: World Ocean Database 2013, Sydney Levitus, Ed.; Alexey Mishonov, Technical Ed.; NOAA Atlas NESDIS 72, 209 pp., 2013.

Casotti, R., Landolfi, A., Brunet, C., D’Ortenzio, F., Mangoni, O., Ribera d'Alcalà, M., and Denis, M.: Composition and dynamics of the phytoplankton of the Ionian Sea (eastern Mediterranean), J. Geophys. Res.-Oceans (1978-2012), 108, C98116, doi:10.1029/2002JC001541, 2003. 
Cetinic, I., Toro-Farmer, G., Ragan, M., Oberg, C., and Jones, B.: Calibration procedure for Slocum glider deployed optical instruments, Optics Express, 17, 15420-15430, 2009.

Chiswell, S.: Annual cycles and spring blooms in phytoplankton: don't abandon Sverdrup completely, MEPS, 443, 39-50, 2011.

Christaki, U., Giannakourou, A., Van Wambeke, F., and Grégori, G.: Nanoflagellate predation on auto-and heterotrophic picoplankton in the oligotrophic Mediterranean Sea, J. Plank. Res., 23, 12971310, 2001.

Claustre, H., Fell, F., Oubelkheir, K., Prieur, L., Sciandra, A., Gentili, B., and Babin, M.: Continuous monitoring of surface optical properties across a geostrophic front: Biogeochemical inferences, Limnol. Oceanogr., 45, 309-321, 2000.

Claustre, H., Hooker, S.B., Van Heukelem, L., Berthon, J-F., Barlow, R., Ras, J., Sessions, S., Targa, C., Thomas, C. S., van der Linde, D., and Marty, J. C.: An intercomparison of hplc phytoplankton pigment methods using in situ samples: application to remote sensing and database activities, Mar. Chem., 85, 41-61, 2004

Conkright, M., O’Brien, T., Stephens, K., Locarnini, R., Garcia, H., Boyer, T., and Antonov, J.: World Ocean Atlas 2001, Volume 6: Chlorophyll, Ed. S. Levitus, NOAA Atlas NESDIS 54, US Governement Printing Office, Washington, DC, 46 pp., 2002.

Crise, A., Allen, J., Baretta, J., Crispi, G., Mosetti, R., and Solidoro, C.: The Mediterranean pelagic ecosystem response to physical forcing, Prog. Oceanogr., 44, 219-243,1999.

Crombet, Y., Leblanc, K., Quéguiner, B., Moutin, T., Rimmelin, P., Ras, J., Claustre, H., Leblond, N., Oriol, L., and Pujo-Pay, M.: Deep silicon maxima in the stratified oligotrophic Mediterranean Sea, Biogeosciences, 8, 459-475, doi:10.5194/bg-8-4592011, 2011.

Cullen, J.: The Deep Chlorophyll Maximum - Comparing Vertical Profiles of Chlorophyll-A, Can. J. Fish. Aqua. Sci., 39, 791-803, 1982.

Cullen, J. J.: Subsurface chlorophyll maximum layers: enduring enigma or mystery solved?, Ann. Rev. Mar. Sci., 7, 207-239, 2015.

Cullen, J. and Lewis, M.: Biological Processes and Optical Measurements Near the Sea Surface: Some Issues Relevant to Remote Sensing, J. Geophys. Res.-Oceans, 100, 13255-13266, 1995.

de Boyer Montegut, C., Madec, G., Fischer, A., Lazar, A., and Iudicone, D.: Mixed layer depth over the global ocean: An examination of profile data and a profile-based climatology, J. Geophys. Res.-Oceans, 109, C12003, doi:10.1029/2004JC002378, 2004.

Devred, E., Sathyendranath, S., and Platt, T.: Delineation of ecological provinces using ocean colour radiometry, Mar. Ecol. Prog. Ser., 346, 1-13, 2007.

Dolan, J., Vidussi, F., and Claustre, H.: Planktonic ciliates in the Mediterranean Sea: longitudinal trends, Deep Sea Res. Pt. I, 46, 2025-2039, 1999.

Dolan, J., Claustre, H., Carlotti, F., Plounevez, S., and Moutin, T.: Microzooplankton diversity: relationships of tintinnid ciliates with resources, competitors and predators from the Atlantic Coast of Morocco to the Eastern Mediterranean, Deep Sea Res. Pt. I, 49, 1217-1232, 2002.

D'Ortenzio, F. and Ribera d'Alcalà , M.: On the trophic regimes of the Mediterranean Sea: a satellite analysis, Biogeosciences, 6, 139-148, doi:10.5194/bg-6-139-2009, 2009.
D'Ortenzio, F. and Prieur, L.: The upper mixed layer, Life in the Mediterranean Sea: A look at habitat changes, edited by: Noga Stambler, Nova Science Publisher, 127-156, 2012.

D’Ortenzio, F., Iudicone, D., Montegut, C., Testor, P., Antoine, D., Marullo, S., Santoleri, R., and Madec, G.: Seasonal variability of the mixed layer depth in the Mediterranean Sea as derived from in situ profiles, Geophys. Res. Lett., 32, L12605, doi:10.1029/2005GL022463, 2005.

D'Ortenzio, F., Thierry, V., Eldin, G., Claustre, H., Testor, P., Coatanoan, C., Tedetti, M., Guinet, C., Poteau, A., Prieur, L., and Lefevre D., Bourrin F., Carval T., Goutx M., Garçon V., Thouron D., Lacombe M., Lherminier P., Loisiel H., Mortier L., and Antoine D.: White Book on Oceanic Autonomous Platforms for Biogeochemical Studies: Instrumentation and Measure (PABIM) version 1.3, available from: http://www.obs-vlfr. fr/OAO/file/PABIM_white_book_version1.3.pdf, 2010.

D’Ortenzio, F., Lavigne, H., Besson, F., ClaLavigne, H., Coppola, L., Garcia, N., Laes-Huon, A.s-Huon, A., Le Reste, S., Malardé, D., Migon, C., Morin, P., Mortier, L., Poteau, A., Prieur, L., Raimbault, P., and Testor, P.: Observing mixed layer depth, nitrate and chlorophyll concentrations in the northwestern Mediterranean: A combined satellite and $\mathrm{NO}_{3}$ profiling floats experiment, Geophys. Res. Lett., 41, 6443-6451, doi:10.1002/2014GL061020, 2014.

Dugdale, R. and Wilkerson, F.: Nutrient sources and primary production in the Eastern Mediterranean, Oceanol. Acta, 9, 179184, 1988.

Durrieu de Madron, X., Guieu, C., Sempéré, R., Conan, P., Cossa, D., D’Ortenzio, F., Estournel, C., Gazeau, F., Rabouille, C., Stemmann, L., Bonnet, F. Diaz, P. Koubbi, O. Radakovitch, M. Babin, M. Baklouti, Bancon-Montignya, C., Belviso, S., Bensoussan, N., Bonsang, B., Bouloubassi, I., Brunet, C., Cadiou, J.-F., Carlotti, F., Chami, M., Charmasson, S., Charrière, B., Dachsa, J., Doxaran, D., Dutay, J.-C., and Elbaz-Poulicheta, F.: Marine ecosystems responses to climatic and anthropogenic forcings in the mediterranean, Prog. Oceanogr., 91, 97-166, 2011.

Estrada, M., Marrase, C., Latasa, M., Berdalet, E., Delgado, M., and Riera, T.: Variability of deep chlorophyll maximum characteristics in the Northwestern Mediterranean, Mar. Ecol.-Prog. Ser., 92, 289-289, 1993.

Feldman, G., Kuring, N., Ng, C., Esaias, W., McClain, C., Elrod, J., Maynard, N., and Endres, D.: Ocean-color: availability of the global data set, EOS, p. 634, 1989.

Franz, B., Werdell, P., Meister, G., Bailey, S., Eplee, R., Feldman, G., Kwiatkowskaa, E., McClain, C., Patt., F., and Thomas, D.: The continuity of ocean color measurements from SeaWiFS to MODIS, in: Earth observing systems: X. Proceedings SPIE, edited by: Butler, J. J., vol. 5882, The International Society for Optical Engineering, 1-13, 2005.

Gieskes, W. W. and Kraay, G. W.: Unknown Chlorophyll a Derivatives in the North Sea and the Tropical Atlantic Ocean Revealed by HPLC Analysis, Limnol. Oceanogr., 28, 757-766, 1983.

Huisman, J., Oostveen, P. v., and Weissing, F. J.: Critical Depth and Critical Turbulence: Two Different Mechanisms for the Development of Phytoplankton Blooms, Limnol. Oceanogr., 44, 17811787, 1999.

Ignatiades, L., Gotsis-Skretas, O., Pagou, K., and Krasakopoulou, E.: Diversification of phytoplankton community structure and re- 
lated parameters along a large-scale longitudinal east-west transect of the Mediterranean Sea, J. Plank. Res., 31, 411-428, 2009.

Johnson, K. S., Berelson, W. M., Boss, E. S., Chase, Z., Claustre, H., Emerson, S. R., Gruber, N., Kortzinger, A., Perry, M. J., and Riser, S. C.: Observing biogeochemical cycles at global scales with profiling floats and gliders: Prospects for a global array, Oceanography, 22, 216-225, 2009.

Kiefer, D. A.: Fluorescence properties of natural phytoplankton populations, Mar.Biol., 22, 263-269, 1973.

Kolber, Z. and Falkowski, P. G.: Use of Active Fluorescence to Estimate Phytoplankton Photosynthesis in Situ, Limnol. Oceanogr., 38, 1646-1665, 1993.

Krom, M., Brenner, S., Kress, N., Neori, A., and Gorgon, L.: Nutrient Dynamics and New Production in a Warm-Core Eddy from the Eastern Mediterranean-Sea, Deep-Sea Res. Pt. A, 39, 467480, 1992.

Krom, M. D., Kress, N., Brenner, S., and Gordon, L. I.: Phosphorus Limitation of Primary Productivity in the Eastern Mediterranean Sea, Limnol. Oceanogr., 36, 424-432, 1991.

Lavigne, H., D’Ortenzio, F., Claustre, H., and Poteau, A.: Towards a merged satellite and in situ fluorescence ocean chlorophyll product, Biogeosciences, 9, 2111-2125, doi:10.5194/bg-9-21112012, 2012.

Lavigne, H., D’Ortenzio, F., Migon, C., Claustre, H., Testor, P., d'Alcal Ã , M. R., Lavezza, R., Houpert, L., and Prieur, L.: Enhancing the comprehension of mixed layer depth control on the Mediterranean phytoplankton phenology, J. Geophys. Res.Oceans, 118, 3416-3430, 2013.

Letelier, R. M., Karl, D. M., Abbott, M. R., and Bidigare, R. R.: Light Driven Seasonal Patterns of Chlorophyll and Nitrate in the Lower Euphotic Zone of the North Pacific Subtropical Gyre, Limnol. Oceanogr., 49, 508-519, 2004.

Longhurst, A. R.: Ecological Geography of the Sea, Second Edition, Academic Press, 2 Edn., 2006.

Longhurst, A. R. and Harrison, G. W.: The biological pump: profiles of plankton production and consumption in the upper ocean, Prog. Oceanogr., 22, 47-123, 1989.

Lorenzen, C. J.: A method for the continuous measurement of in vivo chlorophyll concentration, Deep-Sea Res., 13, 223-227, 1966.

Macias, D., Stips, A., and Garcia-Gorriz, E.: The relevance of deep chlorophyll maximum in the open Mediterranean Sea evaluated through 3D hydrodynamic-biogeochemical coupled simulations, Ecol. Modell., 281, 26-37, 2014.

Maillard, C. et al.: MEDAR/MEDATLAS 1998-2001: A Mediterranean and Black Sea oceanographic data base and network, 46, 329-344, 2005.

Manca, B., Burca, M., Giorgetti, A., Coatanoan, C., Garcia, M.-J., and Iona, A.: Physical and biochemical averaged vertical profiles in the Mediterranean regions: an important tool to trace the climatology of water masses and to validate incoming data from operational oceanography, J. Mar. Syst., 48, 83-116, 2004.

Marty, J.-C., Chiaverini, J., Pizay, M.-D., and Avril, B.: Seasonal and interannual dynamics of nutrients and phytoplankton pigments in the western Mediterranean Sea at the DYFAMED timeseries station (1991-1999), Deep Sea Res. Pt. II, 49, 1965-1985, 2002.
McClain, C., Cleave, M., Feldman, G., Gregg, W., Hooker, S., and Kuring, N.: Science quality SeaWiFS data for global biosphere research, Sea Technol., 39, 10-16, 1998.

Mignot, A., Claustre, H., D’Ortenzio, F., Xing, X., Poteau, A., and Ras, J.: From the shape of the vertical profile of in vivo fluorescence to Chlorophyll $a$ concentration, Biogeosciences, 8, 23912406, doi:10.5194/bg-8-2391-2011, 2011.

Mignot, A., Claustre, H., Uitz, J., Poteau, A., D’Ortenzio, F., and Xing, X.: Understanding the seasonal dynamics of phytoplankton biomass and the deep chlorophyll maximum in oligotrophic environments: A Bio-Argo float investigation, Global Biogeochem. Cy., 28, 856-876, 2014.

Müller, P., Li, X.-P., and Niyogi, K. K.: Non-Photochemical Quenching. A Response to Excess Light Energy, Plant Physiol., 125, 1558-1566, 2001.

Morel, A. and André, J.-M.: Pigment Distribution and Primary Production in the Western Mediterranean as Derived and Modeled From Coastal Zone Color Scanner Observations, J. Geophys. Res., 96, 12685-12698, 1991.

Morel, A. and Berthon, J.: Surface Pigments, Algal Biomass Profiles, and Potential Production of the Euphotic Layer - Relationships Reinvestigated in View of Remote-Sensing Applications, Limnol. Oceanogr., 34, 1545-1562, 1989.

Morel, A. and Maritorena, S.: Bio-optical properties of oceanic waters: A reappraisal, J. Geophys. Res.-Oceans, 106, 7163-7180, 2001.

Moutin, T. and Raimbault, P.: Primary production, carbon export and nutrients availability in western and eastern Mediterranean Sea in early summer 1996 (MINOS cruise), J. Mar. Syst., 33-34, 273-288, 2002.

Moutin, T. and Prieur, L.: Influence of anticyclonic eddies on the Biogeochemistry from the Oligotrophic to the Ultraoligotrophic Mediterranean (BOUM cruise), Biogeosciences, 9, 3827-3855, doi:10.5194/bg-9-3827-2012, 2012.

Moutin, T., Van Wambeke, F., and Prieur, L.: Introduction to the Biogeochemistry from the Oligotrophic to the Ultraoligotrophic Mediterranean (BOUM) experiment, Biogeosciences, 9, 3817 3825, doi:10.5194/bg-9-3817-2012, 2012.

Navarro, G., Vázquez, Á., Macás, D., Bruno, M., and Ruiz, J.: Understanding the patterns of biological response to physical forcing in the Alborán Sea (western Mediterranean), Geophys. Res. Lett., 38, L23606, doi:0.1029/2011GL049708, 2011.

Platt, T., Sathyendranath, S., White III, G. N., Fuentes-Yaco, C., Zhai, L., Devred, E., and Tang, C.: Diagnostic properties of phytoplankton time series from remote sensing, Estuar. Coast., 33, 428-439, 2010.

Psarra, S., Tselepides, A., and Ignatiades, L.: Primary productivity in the oligotrophic Cretan Sea (NE Mediterranean): seasonal and interannual variability, Prog. Oceanogr., 46, 187-204, 2000.

Ribera d'Alcala', M., Civitarese, G., Conversano, F., and Lavezza, R.: Nutrient ratios and fluxes hint at overlooked processes in the Mediterranean Sea, J. Geophys. Res., 108, 8106, doi:10.1029/2002JC001650, 2003.

Rio M.-H., Poulain P.-M., Pascual A., Mauri, E., Larnicol, G., and Santoleri, R.: A mean dynamic topography of the Mediterranean Sea computed from altimetric data, in-situ measurements and a general circulation model, J. Mar. Syst., 65, 484-508, 2007.

Robinson, A. and Golnaraghi, M.: The physical and dynamical oceanography of the Mediterranean Sea, in: Ocean processes in 
climate dynamics: Global and Mediterranean examples, vol. 419 of NATO Science Series, 255-306, 1994.

Röttgers, R. and Koch, B. P.: Spectroscopic detection of a ubiquitous dissolved pigment degradation product in subsurface waters of the global ocean, Biogeosciences, 9, 2585-2596, doi:10.5194/bg-9-2585-2012, 2012.

Sackmann, B. S., Perry, M. J., and Eriksen, C. C.: Seaglider observations of variability in daytime fluorescence quenching of chlorophyll $a$ in Northeastern Pacific coastal waters, Biogeosciences Discuss., 5, 2839-2865, doi:10.5194/bgd-5-2839-2008, 2008.

Sharples, J., Moore, C. M., Rippeth, T. P., Holligan, P. M., Hydes, D. J., Fisher, N. R., and Simpson, J. H.: Phytoplankton Distribution and Survival in the Thermocline, Limnol. Oceanogr., 46, 486-496, 2001

Siegel, D. A., Doney, S. C., and Yoder, J. A.: The North Atlantic Spring Phytoplankton Bloom and Sverdrup's Critical Depth Hypothesis, Science, 296, 730-733, 2002.

Siokou-Frangou, I., Christaki, U., Mazzocchi, M. G., Montresor, M., Ribera d'Alcalà, M., Vaque, D., and Zingone, A.: Plankton in the open Mediterranean Sea: a review, Biogeosciences, 7, 15431586, doi:10.5194/bg-7-1543-2010, 2010.

Sosik, H.M., Chisholm, S. C., and Olson, R. J.: Chlorophyll Fluorescence from Single Cells: Interpretation of flow cytometric signals, Limnol. Oceanogr., 34, 1749-1761, 1989.

Steinberg, D., Carlson, C., Bates, N., Johnson, R., Michaels, A., and Knap, A.: Overview of the US JGOFS Bermuda Atlantic Timeseries Study (BATS): a decade-scale look at ocean biology and biogeochemistry, Deep-Sea Res. Pt. II, 48, 1405-1447, 2001.

Strass, V.: On the calibration of large-scale fluorometric chlorophyll measurements from towed undulating vehicles, Deep Sea Res. Pt. A. Oceanogr. Res. Papers, 37, 525-540, 1990.
Strickland, J.: Production of organic matter in primary stages of the marine food chain, in: Chemical Oceanography, Academic Press, London, edited by: J. P. Riley and G. Skirrow, 477-610, 1965.

Taupier-Letage, I., Puillat, I., Millot, C., and Raimbault, P.: Biological response to mesoscale eddies in the Algerian Basin, J. Geophys. Res.-Oceans (1978-2012), 108, 3245 , doi:10.1029/1999JC000117, 2003.

Thomalla, S. J., Fauchereau, N., Swart, S., and Monteiro, P. M. S.: Regional scale characteristics of the seasonal cycle of chlorophyll in the Southern Ocean, Biogeosciences, 8, 2849-2866, doi:10.5194/bg-8-2849-2011, 2011.

Uitz, J., Claustre, H., Morel, A., and Hooker, S.: Vertical distribution of phytoplankton communities in open ocean: An assessment based on surface chlorophyll, J. Geophys. Res.-Oceans, 111, C08005, doi:10.1029/2005JC003207, 2006.

Volpe, G., Nardelli, B. B., Cipollini, P., Santoleri, R., and Robinson, I. S.: Seasonal to interannual phytoplankton response to physical processes in the Mediterranean Sea from satellite observations, Remote Sens. Environ., 117, 223-235, 2012.

Xing, X., Morel, A., Claustre, H., Antoine, D., D’Ortenzio, F., Poteau, A., and Mignot, A.: Combined processing and mutual interpretation of radiometry and fluorimetry from autonomous profiling Bio-Argo floats: Chlorophyll a retrieval, J. Geophys. Res.-Oceans, 116, C0620, doi:10.1029/2010JC006899, 2011.

Xing, X., Claustre, H., Blain, S., D’Ortenzio, F., Antoine, D., Ras, J., and Guinet, C.: Quenching correction for in vivo chlorophyll fluorescence measured by instrumented elephant seals in the Kerguelen region (Southern Ocean), Limnol. Oceanogr.-Methods, 10, 483-495, 2012.

Yoder, J. A., McClain, C. R., Feldman, G. C., and Esaias, W. E.: Annual cycles of phytoplankton chlorophyll concentrations in the global ocean: A satellite view, Global Biogeochem. Cy., 7, 181193, 1993. 